\title{
Microbial diversity of a closed salt lagoon in the Puertecitos area, Upper Gulf of California
}

\section{Diversidad microbiana de una laguna salada cerrada en el área de Puertecitos en el Alto Golfo de California}

\author{
Jessica A Kozlowski ${ }^{1 *}$, Markes E Johnson², Jorge Ledesma-Vázquez ${ }^{3}$, Daniel Birgel ${ }^{4}$, Jörn Peckmann", \\ Christa Schleper ${ }^{1}$ \\ 1 Department of Ecogenomics and Systems Biology, University of Vienna, Althanstraße 14, Vienna 1090, \\ Austria. \\ 2 Department of Geosciences, Williams College, Williamstown, MA 01267, USA. \\ ${ }^{3}$ Facultad de Ciencias Marinas, Universidad Autónoma de Baja California, Carretera Transpeninsular \\ Ensenada-Tijuana, no. 3917, Fraccionamiento Playitas, CP 22860, Ensenada, Baja California, Mexico. \\ 4 Institute for Geology, Center for Earth System Research and Sustainability, Universität Hamburg, \\ Bundesstraße 55, 20146 Hamburg, Germany. \\ * Corresponding author. E-mail: jessica.kozlowski@univie.ac.at
}

\begin{abstract}
Located $20 \mathrm{~km}$ south of Puertecitos on the Baja California Peninsula, Mexico, is a salt-crusted lagoon with a surface area of approximately $265,000 \mathrm{~m}^{2}$ that is isolated from the adjacent Upper Gulf of California by a 50-m wide berm. The berm rises $2 \mathrm{~m}$ above mean sea level extending for $530 \mathrm{~m}$ across the lagoon's seaward front to bar replenishment by normal seawater except possibly by seepage. On another side of the lagoon an extinct Pliocene volcano, Volcán Prieto, marks an equally abrupt boundary delineated by basalt flows. The lagoon's well-constrained physical geography represents a high-salinity environment under conditions of extreme aridity, flooded only during rare events associated with subtropical storms. The Volcán Prieto Lagoon (so named herein) formed through distinct stages in developmental geomorphology outlined in this study. A duplicate set of sediment cores $(17 \mathrm{~cm}$ in length) were retrieved from the lagoon and sampled for biological associations that record high-diversity colonization and stratification of microbial mats dominated by bacteria. Small subunit ribosomal RNA gene sequencing of different horizons revealed at least 25 major named bacterial phyla and 8 major named archaeal phyla as well as several unnamed candidate taxa from miscellaneous groups. Lipid biomarker analyses of the same horizons revealed that cyanobacteria contributed significantly to biomass production only at shallow depth, whereas the lipids of anoxygenic phototrophic bacteria persisted to a depth of $15 \mathrm{~cm}$, although with decreasing contents. The lipid patterns also showed that sulfate-reducing bacteria became more abundant with depth, whereas the contents of archaeal lipids increased from 1 to $5 \mathrm{~cm}$ depth but remained relatively constant below. Closed lagoons on the Gulf of California are widely distributed over the length of the Baja California Peninsula, but detailed taxonomic studies regarding the diverse microbial communities that colonized these extreme habitats have only begun to shed light on complex colonization patterns.
\end{abstract}

Key words: coastal processes, closed lagoons, Gulf of California, microbial assemblages, lipid biomarkers.

RESUMEN. Veinte kilómetros hacia el sur de Puertecitos, en la península de Baja California, México, se localiza una laguna con un área superficial de $\sim 265,000 \mathrm{~m}^{2}$ que está cubierta por una costra salina y aislada de la parte alta del golfo de California por una berma de $50 \mathrm{~m}$ de ancho. La berma se eleva $2 \mathrm{~m}$ sobre el nivel medio del mar y se extiende por $530 \mathrm{~m}$ a lo largo del frente marino de la laguna evitando el reabastecimiento normal con agua de mar excepto, posiblemente, por filtración. En otro lado de la laguna, un volcán extinto del Plioceno, el volcán Prieto, marca un límite igualmente abrupto delineado por los flujos de basalto. La geografía física bien delimitada de la laguna representa un entorno de alta salinidad en condiciones de extrema aridez, inundada solo durante eventos poco frecuentes asociados con tormentas subtropicales. La laguna Volcán Prieto (así llamada aquí) se formó a través de distintas etapas en el desarrollo de la geomorfología descrita en este estudio. Se recuperó un conjunto duplicado de núcleos de la laguna (17 cm de longitud) y se tomaron muestras para determinar asociaciones biológicas que registran la colonización de alta diversidad y la estratificación de tapetes microbianos dominados por bacterias. Con base en la secuenciación de genes de ARN ribosómico de subunidades pequeñas de diferentes horizontes, se identificaron al menos 25 filos bacterianos nombrados principales y 8 filos de arqueas nombrados principales, así como varios taxones candidatos sin nombre de grupos diversos. Los análisis de biomarcadores lipídicos de los mismos horizontes revelaron que las cianobacterias contribuyeron significativamente a la producción de biomasa únicamente a una profundidad somera, mientras que los lípidos de las bacterias fotótrofas anoxigénicas persistieron a una profundidad de $15 \mathrm{~cm}$, aunque con contenidos decrecientes. Los patrones de lípidos también mostraron que las bacterias reductoras de sulfato se volvieron más abundantes con la profundidad, mientras que los contenidos de los lípidos de las arqueas aumentaron entre 1 y $5 \mathrm{~cm}$ de profundidad y permanecieron relativamente constantes a mayor profundidad. Las lagunas cerradas en el golfo de California están ampliamente distribuidas a lo largo de la península de Baja California, pero los estudios taxonómicos detallados sobre las diversas comunidades microbianas que colonizaron estos hábitats extremos apenas han comenzado a dilucidar los complejos patrones de colonización.

Palabras clave: procesos costeros, lagunas cerradas, golfo de California, ensamblajes microbianos, biomarcadores lipídicos. 


\section{INTRODUCTION}

Microbial mats from lagoons on the outer Pacific coast of the Baja California Peninsula (Mexico) have long been studied (i.e., Horodyski and Vonder Haar 1975, Stolz 1983, Spear et al. 2003, Omoregie et al. 2004). In contrast, lagoons along the inner shores of the peninsula, and on some of the many islands in the Gulf of California, were only recently found to harbor microbial mats (Johnson et al. 2012). In one of the earliest studies, Horodyski and Vonder Haar (1975) referred to their biological discovery at Laguna Mormona as stromatolites - the term applied by geologists and paleontologists to organosedimentary structures now regarded as microbial in origin. Stromatolitic fossils are now recognized as having a Pleistocene history in the Gulf of California (Backus and Johnson 2014), possibly dating back 712,000 y. In a recent overview of coastal ecosystems in the Gulf of California, 5 closed lagoons in the Bahía de Los Ángeles region were identified as habitats for active microbial mats (Johnson and Ledesma-Vázquez 2016). Other lagoons have since been explored, the most recent being Volcán Prieto Lagoon (so named herein), an isolated salt lagoon on the peninsular coast south of Puertecitos, first visited by one of the authors (JLV) in 2011.

Seventy-five kilometers south of the town of San Felipe, Mexican Highway 5 reaches the settlement of Puertecitos (Fig. 1). Three landmarks farther south of Puertecitos dominate the physical geography and related geology along this section of the Gulf of California shore (Fig. 1). Approached from the highway, the most distinctive feature, a coneshaped structure called Volcán Prieto, sits $275 \mathrm{~m}$ above sea level. Mapped as a Pliocene volcano (Gastil et al. 1971), the basalt edifice is crowned by a crater roughly $350 \mathrm{~m}$ in diameter with a basin floor that sits from 8 to $10 \mathrm{~m}$ below the enclosing summit. Adjacent and to the north is a large fan delta that drains a network of streambeds belonging to Arroyo Los Heme (Fig. 2a). The delta takes its name from Playa Costilla at the far north end. At its widest, the delta is $3.75 \mathrm{~km}$ across but the front extends through an arc of $4.75 \mathrm{~km}$. The longest tributary in Arroyo Los Heme follows inland through a winding course of $14 \mathrm{~km}$ entrenched in Pliocene volcanics defined as part of a large ignimbrite field (Stock 2000). At the highway crossing where the outer canyon opens onto the delta, the elevation is $50 \mathrm{~m}$ above sea level. From this low vantage, it is difficult to appraise the delta's three-dimensional form, because the gradient through the central distributary channel to the sea amounts to only $2 \%$. Incised distributary channels indicate that the delta has remained active, but it may have carried a greater sediment load in the past.

The closed lagoon at the south foot of Volcán Prieto is the area's third landmark and the primary focus of this study (Fig. 2b). Crudely trapezoid in map outline, the lagoon front is defined by a coastal berm that fully separates it from the open Gulf of California. The lagoon's maximum length in

\section{INTRODUCCIÓN}

Los mantos microbianos de las lagunas sobre la costa externa del Pacífico de la península de Baja California, México, han sido estudiados desde hace mucho tiempo (i.e., Horodyski y Vonder Haar 1975, Stolz 1983, Spear et al. 2003, Omoregie et al. 2004). Por el contrario, no fue hasta hace poco que se descubrió que las lagunas sobre las costas internas de la península, y en algunas de las muchas islas en el golfo de California, sustentan mantos microbianos (Johnson et al. 2012). En uno de los primeros estudios de este tipo, Horodyski y Vonder Haar (1975) se refirieron a su descubrimiento biológico en la laguna Mormona como estromatolitos-término utilizado por geólogos y paleontólogos para referirse a estructuras órganosedimentarias ahora consideradas de origen microbiano. Hoy en día se reconoce que los estromatolitos fósiles tienen una historia pleistocénica en el golfo de California (Backus y Johnson 2014), que posiblemente data de hace 712,000 años. En una revisión reciente de los ecosistemas costeros en el golfo de California, 5 lagunas cerradas en la región de bahía de los Ángeles fueron identificadas como hábitats de mantos microbianos activos (Johnson y Ledesma-Vázquez 2016). Otras lagunas han sido exploradas desde entonces. La más reciente de estas es la laguna Volcán Prieto (así llamada aquí), una laguna salada aislada en la costa peninsular al sur de Puertecitos, visitada por uno de los autores (JLV) por primera vez en 2011.

Setenta y cinco kilómetros al sur de la población de San Felipe, la carretera federal mexicana 5 alcanza la población de Puertecitos (Fig. 1). Más al sur de Puertecitos, 3 elementos geográficos dominan la geografía física y la geología relacionada a lo largo de esta sección de la costa del golfo de California (Fig. 1). Desde la carretera, el rasgo más distintivo, una estructura volcánica con forma cónica llamada volcán Prieto, se eleva a $275 \mathrm{~m}$ sobre el nivel del mar. Cartografiado como un volcán pliocénico (Gastil et al. 1971), la estructura basáltica culmina en un cráter con un diámetro de $\sim 350 \mathrm{~m}$ con un piso a $8-10 \mathrm{~m}$ por debajo de la cima circundante. Adyacente y hacia el norte se encuentra un abanico deltaico extenso que drena una red de cauces del arroyo Los Heme (Fig. 2a). El delta recibe su nombre de la playa Costilla, ubicada en el extremo norte. En su parte más amplia, el delta mide $3.75 \mathrm{~km}$ transversalmente, pero la parte frontal se extiende en un arco de $4.75 \mathrm{~km}$. El tributario más largo del arroyo Los Heme se adentra en el territorio por medio de un cauce sinuoso de $14 \mathrm{~km}$ tallado en las rocas volcánicas pliocénicas definidas como parte de un gran campo de ignimbrita (Stock 2000). En el cruce de la carretera donde el cañón exterior se abre hacia el delta, la elevación es de $50 \mathrm{~m}$ sobre el nivel del mar. Desde este punto, es difícil visualizar la forma tridimensional del delta, debido a que el gradiente del canal distributario central al mar solo llega al $2 \%$. Los canales distributarios tallados en el terreno indican que el delta ha seguido activo, pero posiblemente transportaba una cantidad de sedimento mayor en el pasado.

La laguna cerrada al pie de la ladera sur del volcán Prieto es el tercer elemento geográfico sobresaliente del área y el 

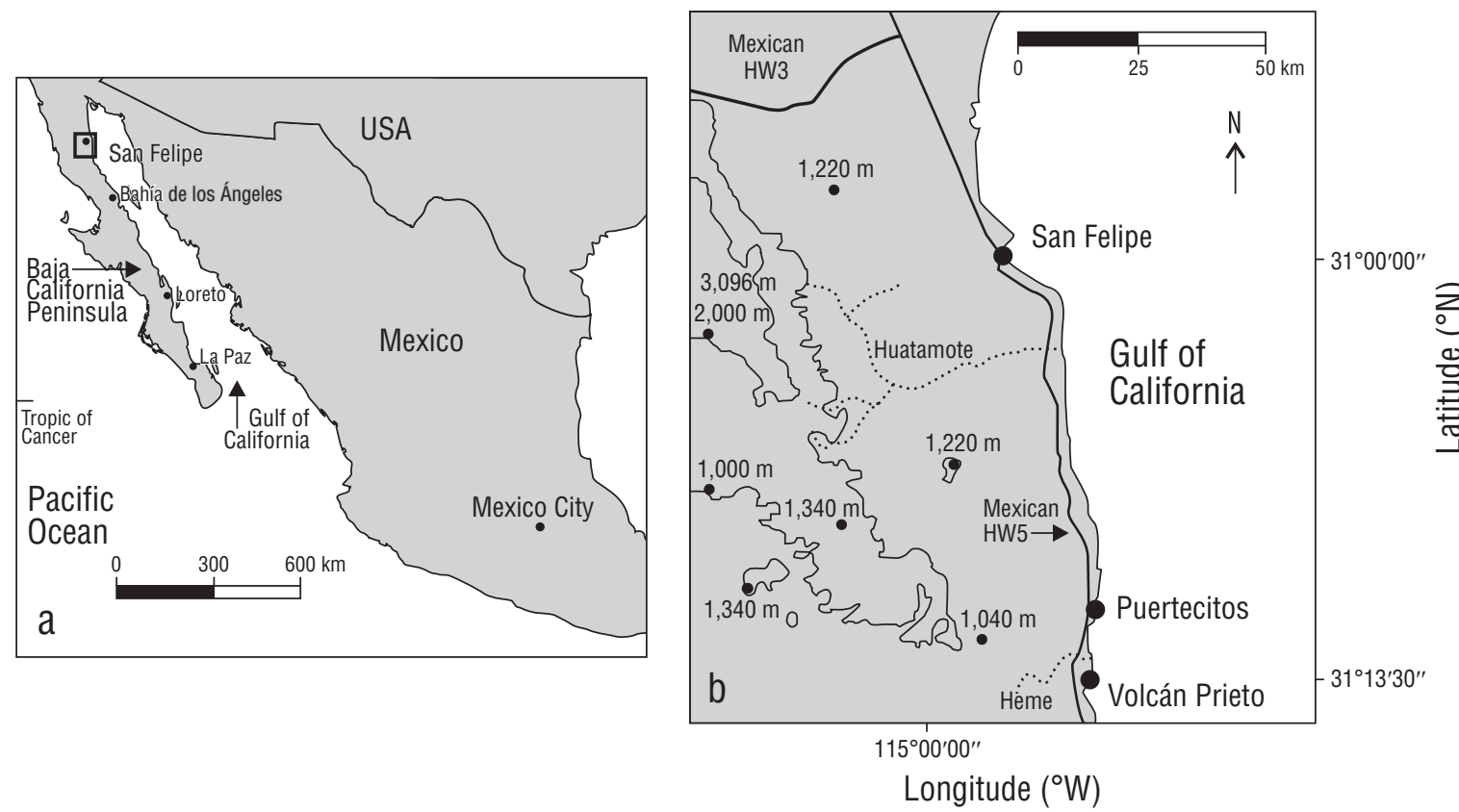

Figure 1. (a) Map showing the Gulf of Mexico and the Baja California Peninsula in relation to mainland Mexico; the box indicates the overall study region. (b) Map enlargement of the study region showing localities on the upper gulf coast of Baja California (HW stands for highway).

Figura 1. (a) Mapa que muestra el golfo de California y la península de Baja California en relación con el resto de México; el rectángulo indica el área de estudio general. (b) Mapa amplificado del área de estudio donde se muestran las localidades en la costa de Baja California en la parte alta del golfo de California (HW indica carretera federal).

the landward direction is $750 \mathrm{~m}$. A surface crust of white salt blankets much of the isolated lagoon (Fig. 2b). All 3 landmarks - the northern delta, the extinct volcano, and the southern lagoon - share essential thematic relationships in the area's overall geomorphological history as related to patterns of local oceanic and atmospheric circulation in the Upper Gulf of California.

The Volcán Prieto Lagoon offers an excellent subject for complimentary studies on functional geomorphology and microbiology. The aims of this contribution are 2-fold: (1) to provide an overview of the physical geography of a closed lagoon and the stages through which it developed during post-Pliocene time, and (2) to offer a state-of-the-art case study on the rich biodiversity of microbial life, including both bacteria and archaea, in such an extreme habitat.

\section{MATERIALS AND METHODS}

\section{Photography and site description}

Perspective on the area's key landmarks was gained during an overflight and from the aerial photographs that were taken. In the field, Volcán Prieto was climbed for the additional opportunities it provided for oblique views of Delta Costilla to the north and the Volcán Prieto Lagoon to the south. The lagoon's berm was traversed for observations on its composition and construction. Other lagoon margins were examined for additional potential features regarding its history. tema central de este estudio (Fig. 2b). Burdamente trapezoidal en los mapas, la parte frontal de la laguna se define por una berma costera que la separa completamente del golfo de California. La longitud máxima de la laguna en dirección tierra adentro es de $750 \mathrm{~m}$. Una costra superficial de sal blanca cubre la mayor parte de la laguna aislada (Fig. 2b). Los 3 elementos geográficos (el delta al norte, el volcán extinto y la laguna al sur) comparten relaciones temáticas esenciales en la historia geomorfológica general del área con respecto a los patrones de circulación oceánica local y atmosférica en la parte alta del golfo de California.

La laguna Volcán Prieto es un sujeto excelente para estudios complementarios sobre la geomorfología funcional y la microbiología. Este estudio tiene 2 objetivos: (1) proporcionar una perspectiva general de la geografía física de una laguna cerrada y las etapas a través de las cuales se desarrolló durante tiempos posteriores al Pliocéno y (2) ofrecer un estudio de caso sobre el estado de la riqueza de la biodiversidad de la vida microbiana, incluidas las bacterias y arqueas, en un hábitat tan extremo.

\section{Materiales Y MÉTOdos}

\section{Fotografía y descripción del sitio}

Se obtuvo una perspectiva de los elementos geográficos sobresalientes del área durante un sobrevuelo y a través de las fotografías aéreas que se tomaron. En campo, el volcán 

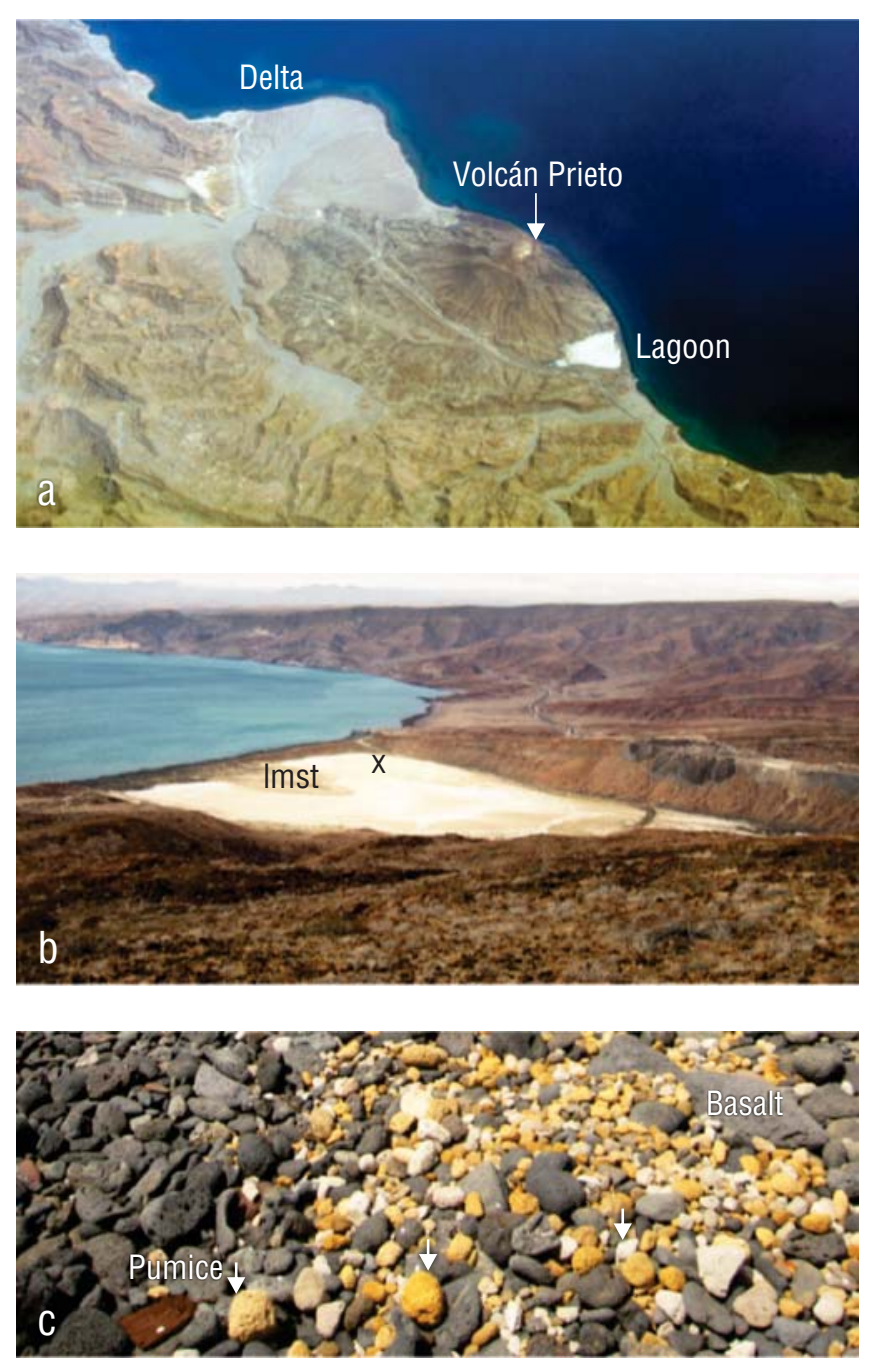

Figure 2. Photographs detailing the geomorphology around Volcán Prieto, south of Puertecitos, Baja California: (a) aerial photograph showing the prominent delta at the mouth of Arroyo Los Hemme, the cone and crater of Volcán Prieto, and the adjacent closed lagoon; (b) close view of the closed lagoon from the south flank of Volcán Prieto showing limestone (lmst) exposed in the lagoon and the site (X) where cores with microbialites were retrived; and (c) detailed view of the berm that isolates the lagoon from the open Gulf of California showing pumice cobbles (arrows) and small dark basalt boulders.

Figura 2. Fotografías que detallan la geomorfología alrededor del volcán Prieto al sur de Puertecitos, Baja California: (a) fotografía aérea que muestra el delta prominente en la desembocadura del arroyo Los Heme, el cono volcánico y el cráter del volcán Prieto, y la laguna cerrada adyacente; (b) acercamiento de la laguna cerrada desde la ladera sur del volcán Prieto que muestra la piedra caliza (lmst) expuesta en la laguna y el sitio (X) en el cual se extrajeron los núcleos con microbialitos; y (c) vista detallada de la berma que aísla a la laguna del golfo de California donde se muestran los cantos rodados de piedra pómez (flechas) y las pequeñas rocas de basalto oscuro.
Prieto se escaló debido a que proporciona vistas oblicuas del delta Costilla al norte y de la laguna Volcán Prieto al sur. Se recorrió la berma de la laguna para observar su composición y construcción. Otros márgenes de la laguna fueron examinados para identificar otros rasgos potenciales referentes a su historia.

\section{Muestreo de núcleos}

Se extrajeron 2 núcleos iguales del fondo de la laguna (14 de mayo de 2016) para obtener submuestras para los estudios moleculares. Los sedimentos blandos fueron extraídos con nucleadores de $20 \mathrm{~cm}$ de largo y $4 \mathrm{~cm}$ de diámetro (Fig. 3). Se usaron guantes durante todas las etapas de la extracción de los núcleos y durante el tratamiento posterior de las submuestras. Una espátula metálica limpiada con etanol al 70\% después de cada división de los núcleos fue utilizada para introducir las submuestras (cada una de 0.5 a $2.0 \mathrm{~g}$ ) en tubos de plástico estériles de $15 \mathrm{~mL}$ que contenían el reactivo de almacenamiento RNAlater (Sigma-Aldrich, Life Science) para preservar el ácido nucleico. La proporción de solución RNAlater a muestra se mantuvo en 5:1. Las tapaderas de los tubos se cubrieron en parafilm para prevenir la contaminación. Cada núcleo produjo un conjunto de 4 submuestras recolectadas en intervalos de $5 \mathrm{~cm}$ desde la parte superior del núcleo.

\section{Extracción y cuantificación del ADN genómico}

Las muestras se lavaron en el laboratorio (Universidad de Viena) con el tampón fosfato salino (PBS, por sus siglas en inglés) para eliminar la solución RNAlater. Para extraer el ADN de las muestras lavadas se utilizó un método estándar que incluye la agitación de esferas y la extracción de fenol-cloroformo con el tampón de extracción de CTAB/fosfato al 5\% (Gittel et al. 2014). El ADN genómico se cuantificó con el fluorómetro Qubit 2.0 (Life Technologies) antes de realizar las reacciones en cadena de la polimerasa (PCR, por sus siglas en inglés) y la secuenciación de amplicones.

\section{Secuenciación de amplicones de los genes del ARNr 16S}

Para la amplificación de los genes de la pequeña subunidad del ARN ribosomal (ARNr) mediante PCR, se usó el par de cebadores U519F (5' CAGCMGCCGCGGTAATWC 3') y U805R (5' GACTACHVGGGTATCTAATCC 3') (región V3-V4) para obtener fragmentos de genes de $\sim 300 \mathrm{pb}$. Se realizó la preparación de la biblioteca y la codificación por barras, y se llevó a cabo la secuenciación de alto rendimiento de forma interna en una Personal Genome Machine de Ion Torrent usando química de $300 \mathrm{pb}$ y un Chip Ion 316 v.2 (Life Technologies). El control de la calidad y la depuración de los datos de secuenciación se realizaron con PRINSEQ permitiendo un máximo y mínimo 


\section{Core sampling}

From the lagoon floor, 2 replicate cores were retrieved (14 May 2016) to obtain subsamples for molecular studies. Soft sediments were extracted using core barrels measuring $20 \mathrm{~cm}$ in length and $4 \mathrm{~cm}$ in diameter (Fig. 3). Gloves were worn during all stages of core retrieval and further treatment of subsamples. A metal spatula cleaned with $70 \%$ ethanol after each partition of the sample cores was used to introduce subsamples (each between 0.5 to $2.0 \mathrm{~g}$ ) into $15-\mathrm{mL}$ sterile plastic tubes containing RNAlater storage reagent (Sigma-Aldrich, Life Science) to preserve the nucleic acids. The ratio of RNAlater solution to sample was kept at 5:1. Vial caps were wrapped with parafilm to prevent contamination. Each core yielded a set of 4 subsamples collected at 5 - $\mathrm{cm}$ intervals from the top of the core.

\section{Genomic DNA extraction and quantification}

Samples were washed in the laboratory (University of Vienna) with PBS buffer to remove RNAlater solution. A standard DNA extraction procedure including bead-beating and phenol-chloroform extraction with 5\% CTAB/phosphate extraction buffer was used on washed samples (Gittel et al. 2014). Genomic DNA was quantified with a Qubit 2.0 Fluorometer (Life Technologies) before use in polymerase chain reaction (PCR) and amplicon sequencing.

\section{Amplicon sequencing of 16S rRNA genes}

For PCR amplification of small subunit ribosomal RNA (rRNA) genes, the primer pair U519F (5' CAGCMGCCGCGGTAATWC 3') and U805R (5' GACTACHVGGGTATCTAATCC $3^{\prime}$ ) (V3-V4 region) was used in PCR to obtain gene fragments of approximately $300 \mathrm{bp}$. Library preparation and barcoding were performed, and highthroughput sequencing was done in-house on an Ion Torrent Personal Genome Machine using $300 \mathrm{bp}$ chemistry and an Ion 316 v.2 Chip (Life Technologies). Sequencing data were quality filtered and trimmed with PRINSEQ allowing for a minimum and maximum read length of $220 \mathrm{bp}$ and $310 \mathrm{bp}$, respectively. Quality of the sequences was then confirmed with FastQC v.0.11.5 before taxonomic assignment. Reads were clustered into operational taxonomic units (OTUs) with a 97\% DNA sequence similarity cutoff and assigned using QIIME I (Caporaso et al. 2010) with the SILVA SSU Ref NR release 128 database as reference (Quast et al. 2013). QIIME I was also used to make rarefaction curves and principal coordinates analysis plots.

\section{Lipid biomarkers}

Four core subsamples (core 1) were dried in an oven at $40{ }^{\circ} \mathrm{C}$ for $48 \mathrm{~h}$, obtaining $\sim 4 \mathrm{~g}$ of dry material for biomarker analysis. The samples were saponified with $6 \%$

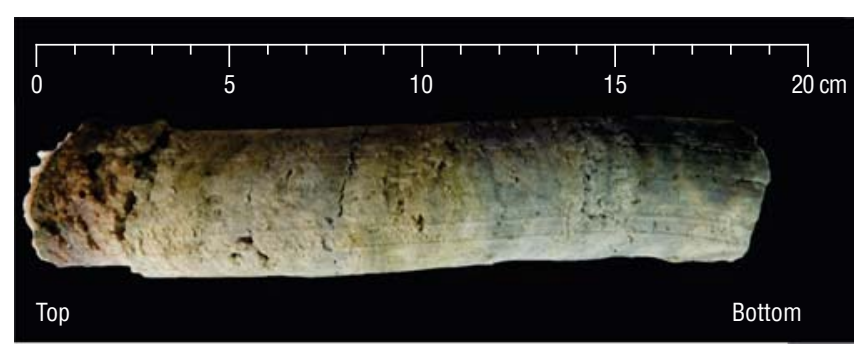

Figure 3. Extruded core from the floor of the Volcán Prieto Lagoon showing variations in layering with depth.

Figura 3. Núcleo extraído del fondo de la laguna Volcán Prieto que muestra las variaciones en las capas con la profundidad.

de lectura de $220 \mathrm{pb}$ y $310 \mathrm{pb}$, respectivamente. La calidad de las secuencias se confirmó con FastQC v.0.11.5 antes de la asignación taxonómica. Las lecturas fueron agrupadas en unidades taxonómicas operacionales (UTO) con un corte de similitud de la secuenciación del ADN del 97\% y fueron asignadas usando QIIME I (Caporaso et al. 2010) con la base de datos SILVA SSU Ref NR v.128 como referencia (Quast et al. 2013). QIIME I también se utilizó para generar curvas de rarefacción y graficas del análisis de coordenadas principales.

\section{Biomarcadores lípidos}

Se secaron 4 submuestras del núcleo 1 en un horno a $40^{\circ} \mathrm{C}$ por $48 \mathrm{~h}$, lo cual proporcionó $\sim 4 \mathrm{~g}$ de material seco para el análisis de biomarcadores. Las muestras se saponificaron con hidróxido de potasio al $6 \%$ en metanol y se extrajeron 3 veces por medio de ultrasonido con diclorometano:metanol (3:1). Los extractos de lípidos totales se separaron previamente en fracciones solubles en $n$-hexano y fracciones solubles en diclorometano. Las fracciones solubles en $n$-hexano se separaron, además, en fracciones con polaridad incrementada por medio de cromatografía en columna (ver Birgel et al. 2008). Los alcoholes se derivatizaron con BSTFA (N,O-bis-trimetilsilil-trifluoroacetamida) y piridina $(1: 1)$ a $70{ }^{\circ} \mathrm{C}$ por $1 \mathrm{~h}$. Los ácidos carboxílicos se metilaron con trifloruro de boro al $20 \%$ en metanol a $70{ }^{\circ} \mathrm{C}$ por $1 \mathrm{~h}$. Los compuestos se midieron en un cromatógrafo de gases acoplado a un espectrómetro de masas (CG-EM) DSQ II de Thermo Electron Trace, y los espectros de masas obtenidos se compararon con los espectros de masas de las bibliotecas y con las muestras de referencia. El CG-EM estaba equipado con una columna capilar de sílice fundida HP-5 MS IU de $30 \mathrm{~m}(0.25 \mathrm{~mm}$ de diámetro interno, $0.25 \mu \mathrm{m}$ de grosor de película). El gas portador era helio. El programa de calentamiento para la extracción de ambas fracciones fue el siguiente: $50{ }^{\circ} \mathrm{C}$ por $3 \mathrm{~min}$, incremento de 50 a $230{ }^{\circ} \mathrm{C}$ a $25^{\circ} \mathrm{C}$ por minuto, y un tiempo de retención de $3 \mathrm{~min}$. Después, se elevó la temperatura de 230 a $325^{\circ} \mathrm{C}$ a $6{ }^{\circ} \mathrm{C}$ por minuto. Finalmente, se mantuvo la temperatura a $325^{\circ} \mathrm{C}$ por $15 \mathrm{~min}$. 
potassium hydroxide in methanol and extracted 3 times by ultrasonication with dichloromethane:methanol $(3: 1)$. Total lipid extracts were pre-separated into $n$-hexane-soluble and dichloromethane-soluble fractions. The $n$-hexane-soluble fractions were further separated by column-chromatography into fractions of increasing polarity (see Birgel et al. 2008). The alcohols were derivatized with BSTFA (N,O-bis-trimethylsilyl-trifluoracetamide) and pyridine (1:1) at $70{ }^{\circ} \mathrm{C}$ for $1 \mathrm{~h}$. The carboxylic acids were methylated with $20 \%$ boron trifluoride in methanol at $70{ }^{\circ} \mathrm{C}$ for $1 \mathrm{~h}$. Compounds were measured on a Thermo Electron Trace DSQ II gas chromatograph/mass spectrometer (GC/MS), and obtained mass spectra were compared with mass spectra from libraries and reference samples. The GC/MS was equipped with a $30 \mathrm{~m}$ HP-5 MS IU fused silica capillary column (0.25 mm internal diameter, $0.25 \mu \mathrm{m}$ film thickness). The carrier gas was helium. The temperature program used for extraction of both fractions was as follows: $50{ }^{\circ} \mathrm{C}$ for $3 \mathrm{~min}$, raised from 50 to $230{ }^{\circ} \mathrm{C}$ at $25^{\circ} \mathrm{C}$ per minute, and finally held for $3 \mathrm{~min}$. Then, temperature was raised from 230 to $325^{\circ} \mathrm{C}$ at $6{ }^{\circ} \mathrm{C}$ per minute. Finally, the temperature was held at $325^{\circ} \mathrm{C}$ for $15 \mathrm{~min}$.

\section{ReSUltS}

\section{Observations on local geomorphology}

Aerial photography showed the proximity of Volcán Prieto on one side of the lagoon (Fig. 2a). The lagoon floor surface area was approximately $265,000 \mathrm{~m}^{2}, 75 \%$ of which was covered by a crust of white salt. An oblique view of the lagoon from a closer range on the south flank of Volcán Prieto (Fig. 2b) showed a dark berm stretching straight across the lagoon front, unbroken for a distance of $530 \mathrm{~m}$. A distinct patch with tan coloration formed a kind of island with low elevation behind the berm at the middle front of the lagoon. This feature turned out to be limestone (Fig. 2b) composed of fossil shells of the marine bivalve Chione californiensis (see Brusca 1980: p. 149, Figure 9.45 for representation of the extant shell).

With a cross-sectional width of $50 \mathrm{~m}$, the berm was constructed from well-rounded basalt cobbles (Fig. 2c) that typically ranged between 10 and $25 \mathrm{~cm}$ in diameter. Less common, basalt boulders (from 30 to $50 \mathrm{~cm}$ across) also occurred on the berm. Pebble- to cobble-sized pieces of pumice occupied a long swath just below the berm crest parallel to the shore on the seaward side. These were orange in color and wellrounded with a maximum diameter of $12 \mathrm{~cm}$ (Fig. 2c). Samples from the pumice apron floated in seawater, and it can be assumed that the material settled on the berm during periods of high tide coinciding with higher than normal waves. The berm crest stood approximately $2 \mathrm{~m}$ above mean sea level. It is noteworthy that no pumice outcrops were observed during a traverse of Volcán Prieto.

Two cores were taken from the outer southern margin of the lagoon (Fig. 2b), where the overlying salt crust was

\section{RESUltados}

\section{Observaciones de la geomorfología local}

La fotografía aérea mostró la proximidad del volcán Prieto a uno de los costados de la laguna (Fig. 2a). El área superficial del fondo de la laguna era de aproximadamente $265,000 \mathrm{~m}^{2}$, el $75 \%$ del cual estaba cubierto por una costra de sal blanca. Una vista oblicua de la laguna desde un punto más cercano sobre el costado sur del volcán Prieto (Fig. 2b) mostró una berma oscura extendida ininterrumpidamente por $530 \mathrm{~m}$ a lo largo de la parte frontal de la laguna. Un parche distintivo de color café claro formaba un tipo de isla con poca elevación detrás de la berma en la parte media del frente de la laguna. Este elemento resultó ser de piedra caliza (Fig. 2b) compuesta de conchas fosilizadas del bivalvo marino Chione californiensis (ver Brusca 1980: p. 149, Fig. 9.45 para la descripción de esta concha aun existente).

Con una sección transversal de $50 \mathrm{~m}$ de ancho, la berma estaba formada por cantos rodados de basalto (Fig. 2c) que medían típicamente entre 10 y $25 \mathrm{~cm}$ de diámetro. También habían rocas de basalto (de 30 a $50 \mathrm{~cm}$ transversales) en la berma, pero eran menos comunes. Habían piezas de piedra pómez, que variaron del tamaño de guijarros al tamaño de cantos rodados, en una franja larga paralela a la línea de costa justo debajo de la cresta de la berma en el lado expuesto al mar. Estas tenían un color naranja, forma redondeada y un diámetro máximo de $12 \mathrm{~cm}$ (Fig. 2c). Las muestras de piedra pómez tomadas de la franja flotaron en agua de mar, y se puede suponer que el material se asentó en la berma durante los periodos en los que la marea alta coincidió con olas de tamaño mayor al normal. La cresta de la berma estaba situada a aproximadamente $2 \mathrm{~m}$ sobre el nivel medio del mar. Se destaca que no se observaron afloramientos de piedra pómez durante el recorrido del volcán Prieto.

Se tomaron 2 núcleos del margen sur exterior de la laguna (Fig. 2b), donde la costra salina era relativamente delegada. El fondo de la laguna era suave y el peso de una persona cruzando el terreno era suficiente para romper la costra salina y exponer el material más oscuro y esponjoso por debajo. La subsuperficie se pudo penetrar con el astil de una pala hasta una profundidad de $60 \mathrm{~cm}$, y al retirarlo, la hendidura resultante se llenó con agua. Esto demuestra que la saturación de agua por debajo de la superficie de la costra era muy alta y estaba en equilibrio con el nivel del mar en el lado opuesto de la berma.

La longitud máxima de los núcleos extrudida del nucleador fue solo de $17 \mathrm{~cm}$ (Fig. 3). Los primeros milímetros del núcleo, directamente debajo de la costra salina, exhibieron un pigmento rojo. Por debajo, se observaron franjas en intervalos que presentaban pigmentos verdes intercalados con intervalos incoloros. Minutos después de ser expuestas al aire, las submuestras seccionadas del núcleo perdieron humedad rápidamente y dieron una apariencia general de arcilla uniforme, ocultando cualquier rastro previo de pigmentos orgánicos. 
Kozlowski et al.: Lagoon geomorphology and microbial diversity

relatively thin. The lagoon floor was soft and the weight of a person crossing the field was sufficient to break through the salt crust to dark, spongy material below. It was possible to penetrate the subsurface to a depth of $60 \mathrm{~cm}$ using the shaft of a shovel and when the probe was withdrawn, the resulting hole filled with water. This demonstrates that water saturation below the crust surface was quite high and in equilibrium with the level of the sea on the opposite side of the berm.

Maximum core length extruded from the core barrel was only $17 \mathrm{~cm}$ (Fig. 3). The top few millimeters of the core, directly below the salt crust exhibited a red pigment. Below, banded intervals occurred that showed a green pigment interspersed with colorless intervals. Within minutes after exposure to the air, subsamples cut from the core soon lost moisture giving the general appearance of uniform clay that concealed any former trace of organic pigmentation.

\section{Abundance and taxonomy of Archaea and Bacteria}

Analysis of 16S rRNA sequence data for relative abundances of bacteria and archaea throughout the replicate cores revealed that bacteria dominated all horizons, making up as much as $95 \%$ of total OTUs from the 10 - and $15-\mathrm{cm}$ horizons of both cores (Table 1). Main bacterial phyla included Proteobacteria, Planctomycetes, and Chloroflexi (Fig. 4). Within the Proteobacteria, the Gamma and Delta classes were most dominant (Fig. 5a). A wide diversity of less abundant bacteria were also observed in all horizons of both cores (Figs. 4, 5a).

When comparing OTUs per horizon, core 1 had a greater number of total OTUs per horizon than core 2, which coincided with less genomic DNA extracted from the respective horizons of core 2 (Table 1). Nevertheless, there were similar trends in the overall microbial community composition between the 2 cores (Figs. 4, 5). The relative abundance

\section{Abundancia y taxonomía de Archea y Bacteria}

El análisis de datos de secuencia del ARNr 16S para la abundancia relativa de las bacterias y arqueas a lo largo de los 2 núcleos reveló que todos los horizontes estaban dominados por bacterias, representando hasta el $95 \%$ de las UTO totales de los horizontes a 10 y $15 \mathrm{~cm}$ de profundidad de ambos núcleos (Tabla 1). Los filos bacterianos más importantes incluyeron Proteobacteria, Planctomycetes y Chloroflexi (Fig. 4). Las clases más dominantes del filo Proteobacteria fueron Gamma y Delta (Fig. 5a). Se observó una gran diversidad de bacterias menos abundantes en todos los horizontes de ambos núcleos (Figs. 4, 5a).

Al comparar las UTO de cada horizonte, el núcleo 1 presentó un mayor número de UTO totales por horizonte que el núcleo 2, lo cual coincidió con la menor cantidad de ADN genómico extraído de los horizontes respectivos del núcleo 2 (Tabla 1). No obstante, las tendencias de la composición general de las comunidades microbianas de los 2 núcleos fueron similares (Figs. 4, 5). En ambos núcleos, la abundancia relativa de arqueas fue más alta en el horizonte a $5 \mathrm{~cm}$ de profundidad (Tabla 1, Fig. 4) y la abundancia relativa de las arqueas estuvo dominada por Euryarchaeota. Euryarchaeota, en particular la clase Halobacteria, representó entre el $40 \%$ y $75 \%$ de la abundancia de arqueas a lo largo de ambos núcleos (Fig. 5b). Además, una diversidad de filos de arquea recientemente identificados, entre ellos Bathyarchaeota, Hadesarchaea y Lokiarchaeota, que apenas empiezan a aparecer en estudios debido al incremento en los esfuerzos de secuenciación y la profundización de los análisis filogenéticos, se presentaron a lo largo de los 2 núcleos (Fig. 5b). Las curvas de rarefacción, creadas con QIIME para las muestras secuenciadas, demostraron que la profundidad de la secuenciación fue suficiente para capturar la diversidad filogenética con la profundidad y entre los 2 núcleos (datos no mostrados). El análisis de las coordenadas

Table 1. Total operational taxonomic units (OTUs) obtained from sequencing of core horizons, including relative abundance of Archaea and Bacteria within each horizon. Concentrations of genomic DNA (gDNA) per extraction also listed.

Tabla 1. Unidades taxonómicas operacionales totales (UTO) obtenidas por la secuenciación de los horizontes de los núcleos; se incluyen las abundancias relativas de Archaea y Bacteria dentro de cada horizonte. También se enlistan las concentraciones del ADN genómico (gDNA).

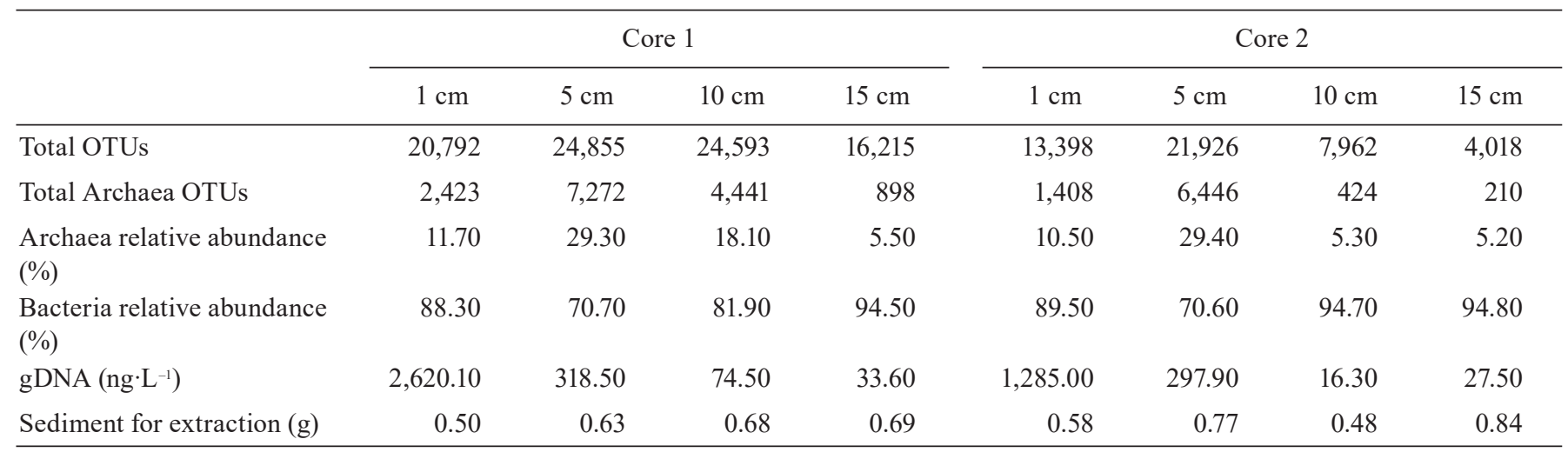


of archaea was highest in both cores at the $5-\mathrm{cm}$ horizon (Table 1, Fig. 4), with Euryarchaeota dominating archaeal relative abundances. Euryarchaeota, particularly the class Halobacteria, made up between $40 \%$ and $75 \%$ of the archaeal abundance throughout both cores (Fig. 5b). Also, a diversity of newly identified archaeal phyla including Bathyarchaeota, Hadesarchaea, and Lokiarchaeota, only now starting to appear in studies due to increased sequencing efforts and in-depth phylogenetic analyses, appeared throughout the 2 cores (Fig. 5b). Rarefaction curves, created for the sequenced samples using QIIME, revealed that the sequencing depth was sufficient to capture phylogenetic diversity among both cores and with depth (data not shown). The principal coordinates analysis showed that the 1-cm layer was the most distinct in both cores and that when comparing the 2 cores, the samples clustered according to depth (data not shown). principales demostró que la capa de $1 \mathrm{~cm}$ era la más distinta en ambos núcleos y que cuando se compararon los 2 núcleos, las muestras se agruparon en función de la profundidad (datos no mostrados).

\section{Biomarcadores lipídicos susceptibles a cromatografía de gases}

La caracterización de la biomasa microbiana presente en el núcleo 1 se realizó por medio del análisis de biomarcadores lipídicos. El peso seco del contenido de los biomarcadores lipídicos varió de $21 \mu \mathrm{g} / \mathrm{g}$ a $10 \mathrm{~cm}$ de profundidad a un máximo de $537 \mu \mathrm{g} / \mathrm{g}$ a $1 \mathrm{~cm}$ de profundidad (Fig. 6). La mayoría de los lípidos se encontraron en la fracción de ácidos carboxílicos, los cuales representaron de $54(10 \mathrm{~cm})$ a $76(15 \mathrm{~cm})$ de porcentaje en masa $(\% \mathrm{~m} / \mathrm{m})$ del total del

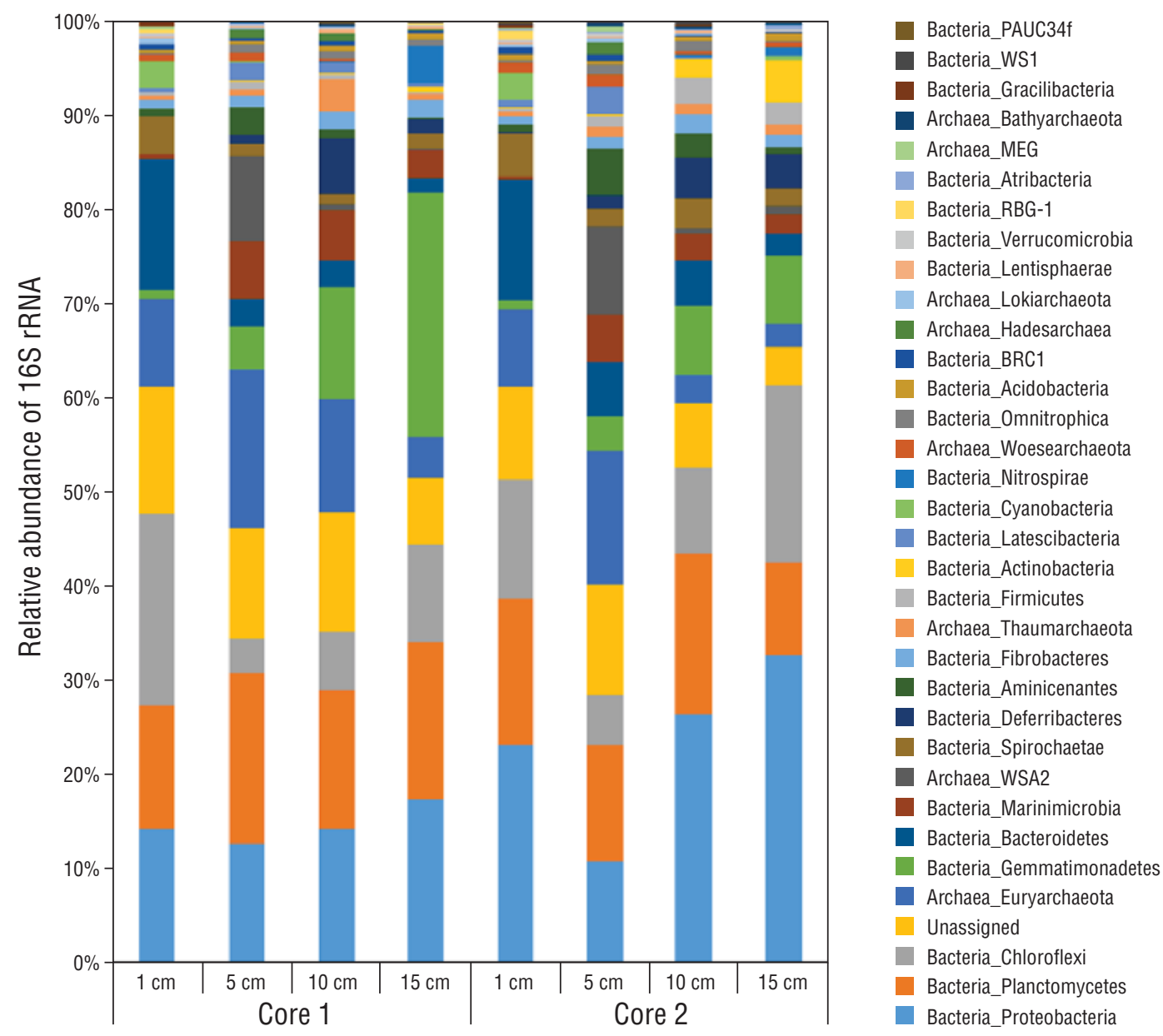

Figure 4. Fluctuation in relative abundance of $16 \mathrm{~S}$ rRNA from major archaeal and bacterial groups through horizons from core 1 and core 2. Bacterial groups PAUC34f, WS1, RBG-1, and BRC-1 represent taxonomic abbreviations for uncultured and/or candidate groups. For archaeal taxonomy, MEG stands for miscellaneous Euryarchaeota group and WSA2 for candidate methanogen class.

Figura 4. Fluctuaciones en la abundancia relativa del ARNr 16S de grupos arqueales y bacterianos principales a través de los horizontes de los núcleos 1 y 2. Las abreviaturas taxonómicas PAUC34f, WS1, RBG-1 y BRC-1 representan grupos bacterianos no cultivados y/o candidatos. Para la taxonomía de las arqueas, MEG representa el grupo misceláneo de Euryarchaeota y WSA2 la clase candidata metanógena. 
a
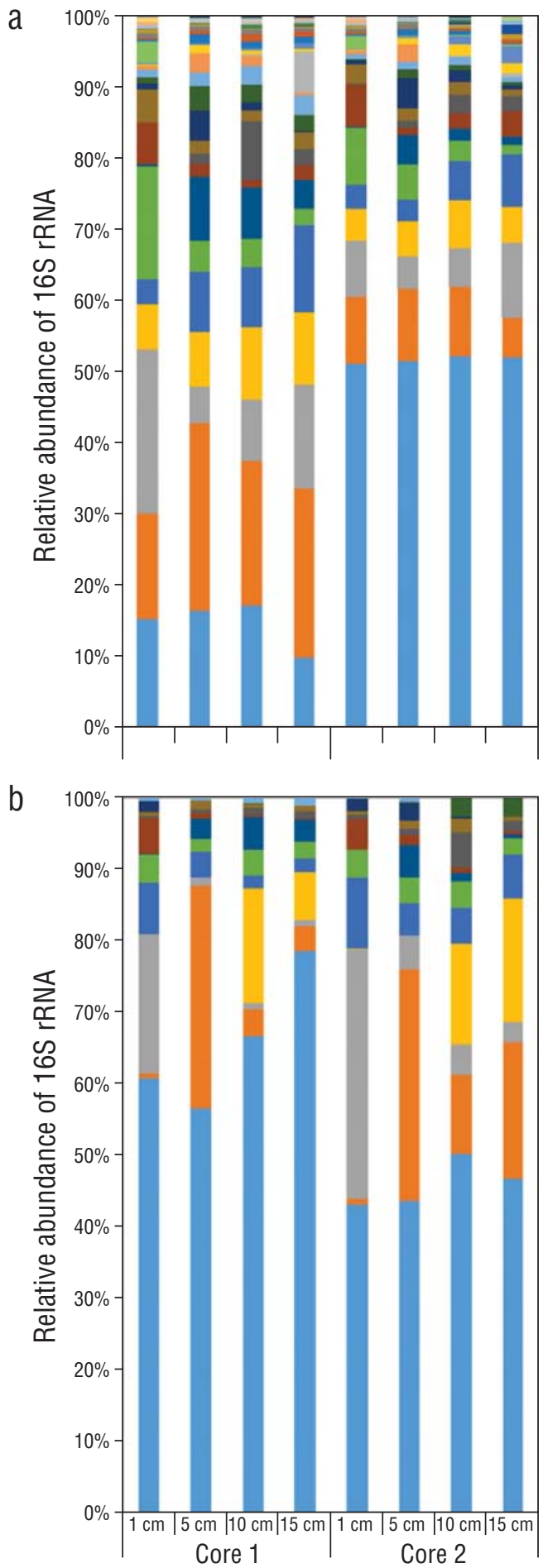

WS1

SBR1093

Proteobacteria_Epsilon

Atribacteria

Gracilibacteria

- PAUC34f

RBG-1 (Zixibacteria)

- Verrucomicrobia

Lentisphaerae

Proteobacteria_Beta

Proteobacteria Other

BRC1

- Acidobacteria

Omnitrophica

Cyanobacteria

- Actinobacteria

Firmicutes

- Nitrospirae

- Latescibacteria

- Fibrobacteres

- Gemmatimonadetes

- Aminicenantes

Spirochaetae

Deferribacteres

Proteobacteria_Alpha

Marinimicrobia (SAR406 clade)

Bacteroidetes

Proteobacteria_Gamma

- Proteobacteria_Delta

- Chloroflexi

- Planctomycetes

- Other
MSBL1

Thaum_SCG

MEG

Other

- Bathyarchaeota

Lokiarchaeota

Hadesarchaea

- Thaum_Group C3

- Woese (DHVEG-6)

- Thaum_Marine group

- Eury_Thermoplasmata

WSA2

Eury_Halobacteria

Figure 5. Relative abundance of $16 \mathrm{~S}$ rRNA from major groups: (a) Bacteria and (b) Archaea. Unassigned sequences or sequences having $<1 \%$ abundance are represented as "other". Bacterial groups WS1, SBR1093, PAUC34f, RBG-1, and BRC-1 represent taxonomic abbreviations for uncultured and/or candidate groups. Abbreviations of archaeal phyla are as follows: Thaum, Thaumarchaeota; Wosese, Woesearchaeota; and Eury, Euryarchaeota. The Thaumarchaeota group is further identified as either soil Crenarchaeota group (SCG), marine group, or group C3 (uncultured archaeon).

Figura 5. Abundancias relativas del ARNr 16S de los grupos principales: (a) Bacteria y (b) Archaea. Las secuencias no asignadas o con abundancia $<1 \%$ se representan como "otros". Los grupos bacterianos WS1, SBR1093, PAUC34f, RBG-1 y BRC-1 representan abreviaciones taxonómicas para grupos no cultivados y/o candidatos. Las abreviaturas de los filos arqueales son las siguientes: Thaum para Thaumarchaeota, Wosese para Woesearchaeota y Eury para Euryarchaeota. El grupo Thaumarchaeota se subdivide en el grupo Crenarchaeota del suelo (SCG), grupo marino o grupo C3 (arqueas no cultivadas). 
a

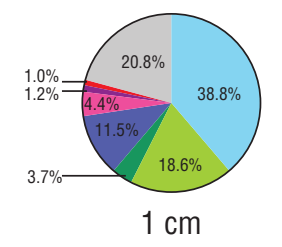

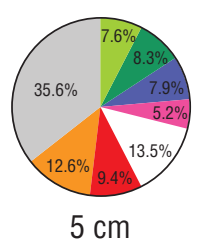

$5 \mathrm{~cm}$

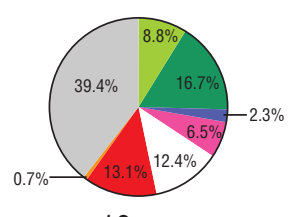

$10 \mathrm{~cm}$

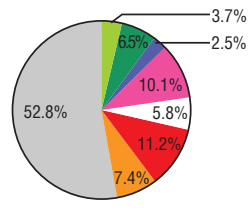

$15 \mathrm{~cm}$
Bacteria (Hopanoids)

Cyanobacteria

Chlorophyll

Algae

Archaea

Unspecified bacteria

Unspecified other source

Sulfate-reducing bacteria

Anoxygenic phototrophs Land plants/algae

(long-chain alkyl lipids)

\section{b}

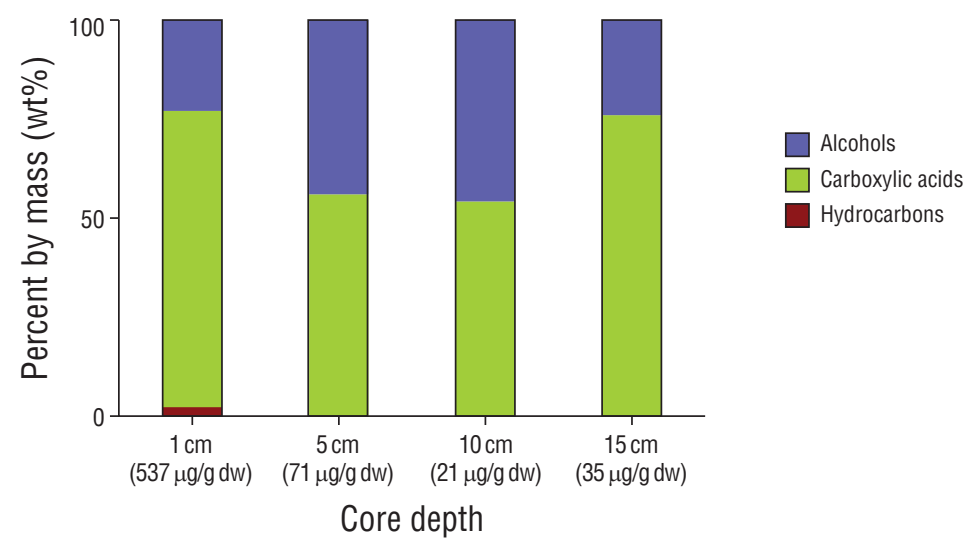

Figure 6. Lipid biomarkers assigned to source organisms and distribution of compound classes relative to depth. (a) Source-specific distribution of lipid biomarkers at 4 different depths in core 1 collected from the 3 fractions shown in (b). (b) Total amount (dw, dry weight) and percentage by mass (wt\%) of all lipid compound classes from the 3 major fractions collected at 4 different depths in core 1 . For a detailed list of biomarkers see Tables $2-4$.

Figura 6. Biomarcadores lipídicos asignados a los organismos fuente y distribución de las clases de compuestos con relación a la profundidad. (a) Distribución de fuentes específicas de biomarcadores lipídicos a 4 profundidades diferentes del núcleo 1 recolectadas de las 3 fracciones diferentes mostradas en (b). (b) Cantidad total (d/w, peso seco) y porcentaje en masa (wt\%) de todas las clases de compuestos lipídicos de las fracciones principales recolectadas a 4 profundidades diferentes del núcleo 1. Para una lista más detallada de los biomarcadores, ver las Tablas $2-4$.

\section{GC-amenable lipid biomarkers}

Characterization of the microbial biomass present in core 1 was done through analysis of lipid biomarkers. Lipid biomarker contents varied from $21 \mu \mathrm{g} / \mathrm{g}$ dry weight at $10 \mathrm{~cm}$ depth to a maximum of $537 \mu \mathrm{g} / \mathrm{g}$ dry weight at $1 \mathrm{~cm}$ depth (Fig. 6). The majority of lipids were found in the carboxylic acid fraction, making up $54(10 \mathrm{~cm})$ to $76(15 \mathrm{~cm})$ percentage by mass ( $\mathrm{wt} \%)$ of the total lipid inventory, followed by alcohols ranging from 23 to $46 \mathrm{wt} \%$. Hydrocarbons were only detected in the uppermost layer $(1 \mathrm{~cm})$ with around $2 \mathrm{wt} \%$ and represented input from only cyanobacteria; at all other depths no biomarkers occurred in the hydrocarbon fraction (Table 2).

The highest amount of source-specific lipids was found in the layer at $1 \mathrm{~cm}$ depth, where $79 \mathrm{wt} \%$ of all lipids were assigned to specific groups and the other $21 \mathrm{wt} \%$ represented by less specific lipids can be either derived from bacteria or eukaryotes (Fig. 6a). The major group of compounds were represented by cyanobacterial lipids (39 wt\%, Table 2), followed by chlorophyll-derived lipids (both bacterial and algal-derived, $19 \mathrm{wt} \%$ ) and lipids from anoxygenic inventario de lípidos, seguido de los alcoholes que representaron de $23 \% \mathrm{~m} / \mathrm{m}$ a $46 \% \mathrm{~m} / \mathrm{m}$. Solo se detectaron hidrocarburos en la capa superficial $(1 \mathrm{~cm})$ con $\sim 2 \% \mathrm{~m} / \mathrm{m}$; a todas las otras profundidades no se presentaron biomarcadores en la fracción de los hidrocarburos (Tabla 2).

La mayor cantidad de lípidos de fuentes especificas se encontró en la capa a $1 \mathrm{~cm}$ de profundidad, en la cual el $79 \% \mathrm{~m} / \mathrm{m}$ de todos los lípidos se asignó a grupos específicos y el $21 \% \mathrm{~m} / \mathrm{m}$ restante representado por lípidos menos específicos puede derivarse de bacterias o de eucariotas (Fig. 6a). Los lípidos cianobacteriales $(39 \% \mathrm{~m} / \mathrm{m}$, Tabla 2) representaron al grupo principal de compuestos, seguidos de los lípidos derivados de la clorofila (derivados de bacterias y de algas, $19 \% \mathrm{~m} / \mathrm{m}$ ) y los lípidos derivados de las bacterias fototróficas anoxigénicas $(12 \% \mathrm{~m} / \mathrm{m})$. Los lípidos arqueales representaron solo el $1 \% \mathrm{~m} / \mathrm{m}$ de todos los lípidos identificados. A 5 y $10 \mathrm{~cm}$ de profundidad, la composición de los lípidos cambió de manera significativa, especialmente debido a la falta de lípidos específicos para las cianobacterias (Fig. 6a, Tablas 2-4). La suma de los lípidos asignados a diferentes grupos de organismos en las fracciones respectivas varió 
phototrophic bacteria $(12 \mathrm{wt} \%)$. Archaeal lipids made up only $1 \mathrm{wt} \%$ of all identified lipids. At 5 and $10 \mathrm{~cm}$ depth, lipid composition changed significantly, especially due to the lack of lipids specific for cyanobacteria (Fig. 6a, Tables 2-4). The sum of lipids assigned to different groups of organisms in the respective fractions ranged from $2 \mathrm{wt} \%$ (anoxygenic phototrophs at $10 \mathrm{~cm}$ ) to $17 \mathrm{wt} \%$ (algae at $10 \mathrm{~cm}$ depth). Compared to the $1 \mathrm{~cm}$ depth sample, the variety of source organisms was greater below, and the contribution of lipids from unspecified sources (bacteria and eukaryotes) increased to 36 and $39 \mathrm{wt} \%$ at $5 \mathrm{~cm}$ and $10 \mathrm{~cm}$, respectively. Archaeal lipids increased to $9 \mathrm{wt} \%$ at $5 \mathrm{~cm}$ depth and $13 \mathrm{wt} \%$ at $10 \mathrm{~cm}$ depth. At $15 \mathrm{~cm}$ depth, the amount of source-specific lipids decreased even more, and archaeal lipids represented $11 \mathrm{wt} \%$ of all lipids. Lipids from archaea and sulfate-reducing bacteria were the most abundant compounds (Tables 3, 4).

Overall, bacteria and eukaryotes were the main sources of the majority of lipids in the studied core. Archaeal lipids measured on the GC/MS included only diether lipids, which are especially prominent in Euryarchaeota. Two diether lipids, archaeol and extended archaeol, were present (Table 3). Whereas archaeol was present at all depths, especially from 5 to $15 \mathrm{~cm}$ depth, extended archaeol was only detected at del $2 \% \mathrm{~m} / \mathrm{m}$ (fotótrofos anoxigénicos a $10 \mathrm{~cm}$ ) al $17 \% \mathrm{~m} / \mathrm{m}$ (algas a $10 \mathrm{~cm}$ de profundidad). Comparada con lo observado en la muestra correspondiente a $1 \mathrm{~cm}$ de profundidad, la variedad de organismos fuente por debajo de esta profundidad era mayor, y la contribución de lípidos de fuentes no especificas (bacterias y eucariotas) incrementó a $36 \% \mathrm{~m} / \mathrm{m}$ y $39 \% \mathrm{~m} / \mathrm{m}$ a 5 y $10 \mathrm{~cm}$, respectivamente. Los lípidos arqueales incrementaron a $9 \% \mathrm{~m} / \mathrm{m}$ a $5 \mathrm{~cm}$ de profundidad y a $13 \%$ $\mathrm{m} / \mathrm{m}$ a $10 \mathrm{~cm}$ de profundidad. A $15 \mathrm{~cm}$ de profundidad, la cantidad de lípidos de fuentes especificas disminuyó aún más y los lípidos arqueales representaron el $11 \% \mathrm{~m} / \mathrm{m}$ de todos los lípidos. Los lípidos arqueales y los de bacterias reductoras de sulfato fueron los compuestos más abundantes (Tablas 3, 4).

En general, las bacterias y las células eucariotas fueron las fuentes principales de la mayoría de los lípidos en el núcleo estudiado. Los lípidos arqueales medidos con el CG-EM solo incluyeron lípidos diéteres, los cuales son especialmente prominentes en Euryarchaeota. Se presentaron 2 lípidos diéteres, arqueol y arqueol extendido (Tabla 3). El arqueol se presentó en todas las profundidades, especialmente entre 5 y $15 \mathrm{~cm}$ de profundidad, mientras que el arqueol extendido solo se detectó a $5 \mathrm{~cm}$ de profundidad, y en cantidades traza a otras profundidades. El arqueol

Table 2. List of hydrocarbon compounds, their sources, and their contents (dw: dry weight) at different depths in core 1.

Tabla 2. Listado de los compuestos de hidrocarburos, sus fuentes y sus contenidos (dw: peso seco) a diferentes profundidades del núcleo 1. *Posición de doble enlace no asignado.

\begin{tabular}{|c|c|c|c|c|c|}
\hline Compound & source & $\begin{array}{c}1 \mathrm{~cm} \\
(\mathrm{mg} / \mathrm{g} \mathrm{dw})\end{array}$ & $\begin{array}{c}5 \mathrm{~cm} \\
(\text { Barren})\end{array}$ & $\begin{array}{c}10 \mathrm{~cm} \\
\text { (Barren) }\end{array}$ & $\begin{array}{c}15 \mathrm{~cm} \\
\text { (Barren) }\end{array}$ \\
\hline$n-C_{15}$ & Unspecified & 0.16 & - & - & - \\
\hline 8-methyl- $\mathrm{C}_{16}$ & Cyanobacteria & 0.18 & - & - & - \\
\hline$n-C_{17: 1} *$ & Cyanobacteria & 0.08 & - & - & - \\
\hline$n-C_{17: 1} *$ & Cyanobacteria & 1.22 & - & - & - \\
\hline$n-\mathrm{C}_{17}$ & Cyanobacteria & 1.99 & - & - & - \\
\hline 8-methyl- $\mathrm{C}_{17}$ & Cyanobacteria & 2.87 & - & - & - \\
\hline 7-methyl- $\mathrm{C}_{17}$ & Cyanobacteria & Traces & - & - & - \\
\hline Phytene* & Chlorophyll & 0.87 & - & - & - \\
\hline$n-\mathrm{C}_{18}$ & Unspecified & 0.17 & - & - & - \\
\hline Phytene* & Chlorophyll & 1.55 & - & - & - \\
\hline Squalene & Chlorophyll & 3.12 & - & - & - \\
\hline Diploptene & Cyanobacteria & 0.48 & - & - & - \\
\hline Sum hydrocarbons & & 12.68 & - & - & - \\
\hline
\end{tabular}

*Position of double bond not assigned 
$5 \mathrm{~cm}$ depth, and in traces at other depths. Extended archaeol is a characteristic biomarker for halophilic euryarchaea (e.g., Dawson et al. 2012). We searched for the second prominent group of archaeal membrane lipids, glycerol dibiphytanyl glycerol tetraethers (GDGTs), using a high-performance liquid chromatography/mass spectrometry system; however, the contents of GDGTs were too low to be detected. extendido es un biomarcador característico de euriarqueas halófilas (e.g., Dawson et al. 2012). Buscamos el segundo grupo de lípidos membranales arqueales más prominente, el glicerol dialquil glicerol tetraéteres (GDGT), usando un sistema de cromatografía líquida de alta resolución y espectrometría de masas; sin embargo, el contenido de GDGT fue demasiado bajo para ser detectado.

Table 3. List of alcohols, their sources, and their contents (dw: dry weight) at different depths in core 1.

Tabla 3. Listado de los alcoholes, sus fuentes y sus contenidos (dw: peso seco) a diferentes profundidades del núcleo 1.

\begin{tabular}{|c|c|c|c|c|c|}
\hline Compound & Source & $\begin{array}{c}1 \mathrm{~cm} \\
(\mathrm{mg} / \mathrm{g} \mathrm{dw})\end{array}$ & $\begin{array}{c}5 \mathrm{~cm} \\
(\mathrm{mg} / \mathrm{g} \mathrm{dw})\end{array}$ & $\begin{array}{c}10 \mathrm{~cm} \\
(\mathrm{mg} / \mathrm{g} \mathrm{dw})\end{array}$ & $\begin{array}{c}15 \mathrm{~cm} \\
(\mathrm{mg} / \mathrm{g} \mathrm{dw})\end{array}$ \\
\hline$n-\mathrm{C}_{14}$-alcohol & Unspecified & 1.94 & 0.18 & - & - \\
\hline$n-\mathrm{C}_{16: 1}$-alcohol & Unspecified & 2.05 & - & - & - \\
\hline$n-\mathrm{C}_{16}$-alcohol & Unspecified & 1.54 & 0.53 & - & - \\
\hline br- $\mathrm{C}_{17}$-alcohol & Unspecified & 0.53 & 0.37 & - & - \\
\hline$n-\mathrm{C}_{17}$-alcohol & Unspecified & - & 0.21 & - & - \\
\hline Phytanol & Chlorophyll & - & 0.58 & - & - \\
\hline$n-C_{18: 1}$-alcohol & Unspecified & 2.97 & - & - & - \\
\hline$n-\mathrm{C}_{18}$-alcohol & Unspecified & 3.28 & 1.06 & 0.55 & 0.56 \\
\hline Phytol & Chlorophyll & 80.89 & 4.72 & 1.61 & 0.74 \\
\hline Tetrahydrogeranylgeraniol & Chlorophyll & 7.51 & - & - & - \\
\hline Geranylgeraniol & Chlorophyll & 1.81 & - & - & - \\
\hline$n-\mathrm{C}_{20}$-alcohol & Unspecified & - & 0.49 & - & - \\
\hline$n-\mathrm{C}_{22}$-alcohol & Unspecified & - & 1.16 & - & 0.88 \\
\hline$n-\mathrm{C}_{24}$-alcohol & Unspecified & - & 0.56 & - & - \\
\hline$n-\mathrm{C}_{26}$-alcohol & Unspecified & - & 1.24 & - & - \\
\hline$n-\mathrm{C}_{28}$-alcohol & Land plants & - & 1.87 & - & 1.04 \\
\hline Cholesterol & Algae & 2.35 & 0.81 & 0.45 & - \\
\hline Cholestanol & Algae & 1.92 & 0.87 & 0.40 & - \\
\hline Brassicasterol & Algae & 1.44 & 0.56 & - & - \\
\hline $28^{\Delta 5}$-sterol & Algae & 4.20 & 0.89 & 0.74 & - \\
\hline $29^{\Delta 5,22}$-sterol & Algae & 1.76 & 1.09 & 0.99 & - \\
\hline$n-\mathrm{C}_{30}$-alcohol & Land plants & - & 1.12 & - & - \\
\hline Sitosterol & Algae & 3.28 & 1.70 & 0.98 & 1.98 \\
\hline $29^{\Delta 0}$-sterol & Others & - & 0.55 & - & - \\
\hline Tetrahymanol & Anoxygenic phototrophs & - & 0.94 & - & - \\
\hline Diplopterol & Unspecified bacteria & - & 1.11 & 1.18 & - \\
\hline Bishomohopanol & Unspecified bacteria & - & 1.79 & - & - \\
\hline Archaeol & Archaea & 5.14 & 5.30 & 2.83 & 3.36 \\
\hline Extended archaeol & Archaea & Traces & 1.36 & Traces & Traces \\
\hline Sum alcohols & & 122.63 & 31.05 & 9.74 & 8.56 \\
\hline
\end{tabular}


Kozlowski et al.: Lagoon geomorphology and microbial diversity

Table 4. List of compounds in the carboxylic acid fraction, their sources, and their contents (dw: dry weight) at different depths in core 1. $\mathrm{FA}=$ fatty acid, $\mathrm{SRB}=$ sulfate-reducing bacteria.

Tabla 4. Listado de compuestos en la fracción de los ácidos carboxílicos, sus fuentes y sus contenidos (dw: peso seco) a diferentes profundidades del núcleo $1 . \mathrm{FA}=$ ácidos grasos, $\mathrm{SRB}=$ bacterias reductoras de sulfato.

\begin{tabular}{|c|c|c|c|c|c|}
\hline iso- $\mathrm{C}_{13}-\mathrm{FA}$ & Bacteria & - & - & - & 0.07 \\
\hline anteiso- $\mathrm{C}_{13}-\mathrm{FA}$ & Bacteria & - & - & - & 0.05 \\
\hline$n-\mathrm{C}_{13}-\mathrm{FA}$ & Unspecified & - & - & - & 0.09 \\
\hline$n-\mathrm{C}_{14}-\mathrm{FA}$ & $\begin{array}{c}\text { Cyanobacteria } \\
(1 \mathrm{~cm})\end{array}$ & 1.87 & 0.42 & 0.34 & 0.76 \\
\hline iso- $\mathrm{C}_{15}$-FA & SRB & 7.10 & 0.56 & 0.31 & 0.50 \\
\hline anteiso- $\mathrm{C}_{15}$-FA & SRB & 2.56 & 0.45 & 0.24 & 0.40 \\
\hline iso- $\mathrm{C}_{16}-\mathrm{FA}$ & Bacteria & 4.68 & 0.73 & 0.29 & 0.60 \\
\hline$n-\mathrm{C}_{16: 1}-\mathrm{FA}$ & $\begin{array}{c}\text { Cyanobacteria } \\
(1 \mathrm{~cm})\end{array}$ & 2.95 & 0.31 & 0.23 & - \\
\hline$n-\mathrm{C}_{16: 1}-\mathrm{FA}$ & $\begin{array}{c}\text { Cyanobacteria } \\
(1 \mathrm{~cm})\end{array}$ & 21.39 & - & - & 0.42 \\
\hline$n-\mathrm{C}_{16}-\mathrm{FA}$ & $\begin{array}{c}\text { Cyanobacteria } \\
(1 \mathrm{~cm})\end{array}$ & 174.80 & 5.40 & 2.20 & 5.02 \\
\hline $10 \mathrm{Me}-\mathrm{C}_{16}-\mathrm{FA}$ & SRB & 6.65 & 0.96 & 0.38 & 1.17 \\
\hline br- $\mathrm{C}_{16}-\mathrm{FA}$ & Bacteria & 1.02 & 0.37 & 0.14 & 0.16 \\
\hline iso- $\mathrm{C}_{18}-\mathrm{FA}$ & Bacteria & - & 0.40 & 0.14 & 0.17 \\
\hline Phytanoic acid & Chlorophyll & 4.89 & 0.68 & 0.26 & 0.37 \\
\hline$n-\mathrm{C}_{18: 1}-\mathrm{FA}$ & Unspecified & 53.38 & 1.53 & 0.77 & 0.83 \\
\hline$n-\mathrm{C}_{18: 1}-\mathrm{FA}$ & Unspecified & 25.20 & 0.56 & - & 0.26 \\
\hline$n-\mathrm{C}_{18}-\mathrm{FA}$ & Unspecified & 20.33 & 3.09 & 1.37 & 2.32 \\
\hline$c y c \mathrm{C}_{19}-\mathrm{FA}$ & Anoxygenic Phototrophs & 61.60 & 4.67 & 0.49 & 0.77 \\
\hline$n-\mathrm{C}_{20}-\mathrm{FA}$ & Unspecific & - & 1.20 & 0.29 & 0.46 \\
\hline$n-\mathrm{C}_{21}-\mathrm{FA}$ & Unspecific & - & 0.34 & - & 0.17 \\
\hline$n-\mathrm{C}_{22: 1}-\mathrm{FA}$ & Unspecific & - & 0.78 & 1.14 & 0.99 \\
\hline$n-\mathrm{C}_{22}-\mathrm{FA}$ & Unspecific & - & 1.32 & 0.31 & 0.76 \\
\hline
\end{tabular}




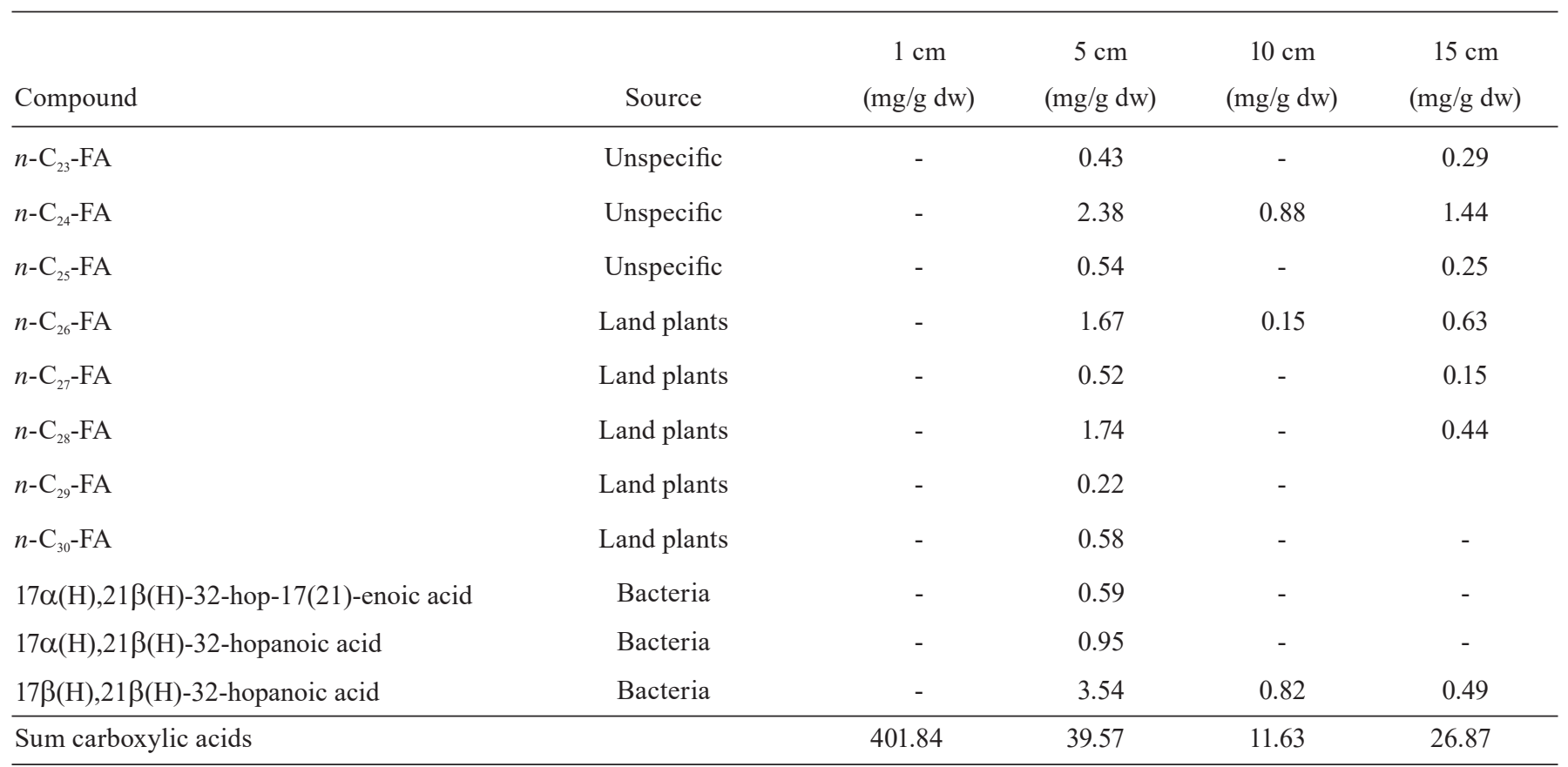

\section{Discussion}

\section{Significance of local geomorphology}

Arid lands attributed to the San Felipe Desert Subregion on the Upper Gulf of California constitute a southwestern extension of the Sonoran Desert. Normally, this area is the driest part of Baja California with an average annual rainfall of $5 \mathrm{~cm}$ (Rebman and Roberts 2012). During the winter months (November through March), strong winds generated by passing high-pressure systems north of the USA-Mexico border may detach and funnel through the axis of the gulf from north to south for several days at a time. These winds are responsible for vigorous longshore currents that scour peninsular shores on the gulf coast, moving beach sediments southward and even affecting the disposition of coastal dunes beyond La Paz in the far south (Johnson and Ledesma-Vázquez 2016). During the summer months (May through September), the wind field over the Gulf of California is prone to reverse itself, often sending lighter, moisture-laden winds northward.

Especially during late summer and early fall, tropical storms that originate off the Mexican mainland coast well south of the Baja California Peninsula intensify in strength and send hurricanes out into the Pacific Ocean (Romero-Vadillo et al. 2007). Every 6 to $8 \mathrm{y}$ during El Niño events, some storms make their way northward into the Gulf of California. The last significant rain storms to affect the San Felipe Desert Subregion occurred in 2003 and 2014 under the influence of hurricanes Marty and Odile, respectively (Johnson and Ledesma-Vázquez 2016). Although downgraded to subtropical storms after initial landfall at the southern end of the

\section{Discusión}

\section{Importancia de la geomorfología local}

Las tierras áridas de la subregión del desierto de San Felipe en el Alto Golfo de California constituyen una extensión del desierto de Sonora al suroeste. Normalmente, esta área es la parte más seca de Baja California con precipitación media anual de $5 \mathrm{~cm}$ (Rebman y Roberts 2012). Durante los meses de invierno (de noviembre a marzo), los vientos fuertes generados por los sistemas de alta presión al norte de la frontera entre Estados Unidos de América y México pueden separarse y canalizarse por el eje del golfo de norte a sur por varios días. Estos vientos generan corrientes litorales que lavan las playas sobre la costa del golfo llevando los sedimentos de las playas hacia el sur e incluso afectando la disposición de las dunas costeras más allá de La Paz (Johnson y Ledesma-Vázquez 2016). Durante los meses de verano (de mayo a septiembre), el campo de viento sobre el golfo de California tiende a revertirse, a menudo con vientos suaves altos en húmedad en dirección hacia el norte.

Especialmente durante el verano tardío y el otoño incipiente, las tormentas tropicales que se producen mucho más al sur de la península de Baja California frente a la costa continental de México se intensifican y conducen a los huracanes hacia el océano Pacífico (Romero-Vadillo et al. 2007). Cada 6 a 8 años durante eventos El Niño, algunas tormentas se desplazan hacia el norte adentrándose en el golfo de California. Las últimas tormentas que afectaron la subregión del desierto de San Felipe de manera significativa ocurrieron en 2003 y 2014 bajo la influencia de los huracanes Marty y 
peninsula near the Tropic of Cancer (Fig. 1), these events brought sudden deluges of rainwater to a climatic zone characterized as a "dry domain" normally controlled by dominant high-pressure systems around $30^{\circ} \mathrm{N}$ (Bailey 1998).

Local evidence of heavy rainfall is apparent across the area under study in this project. Notably, the Volcán Prieto crater, $350 \mathrm{~m}$ in diameter, is floored by silt that shows up in aerial photography as a pair of white patches (Fig. 2a). Exploration of the volcano during fieldwork confirmed that the material on the crater floor derived from a restricted source area on the surrounding crater walls. The only basis for this deposit comes from repeated exposure over time to storm cells that sat above Volcán Prieto for even a few hours at a time.

Delta Costilla immediately north of Volcán Prieto also attests to repeated flood events draining Arroyo Los Heme over time, also resulting in the deep entrenchment of streambeds in the region's greater Pliocene volcanoclastic terrain. Given the lack of pumice on the slopes of Volcán Prieto, it is likely that the pumice cobbles found on the lagoon berm to the south originated inland and were carried to the Gulf of California through Delta Costilla. Once in gulf waters, longshore currents were responsible for transporting the pumice cobbles to the lagoon berm. Essentially, these distinctive cobbles stranded on the lagoon berm are the equivalent of bathtub "yellow duckies" that float around and trace water movements. The more substantial basalt cobbles and boulders on the berm must have their source from the eroded gulf shores of Volcán Prieto.

Paleontological aspects of the Volcán Prieto Lagoon indicate that the place was formerly an embayment with an open connection to the Gulf of California. In particular, the limestone "island" behind the berm at the middle front of the lagoon has abundant fossils dominated by the marine bivalve C. californiensis. The deposit most likely dates from the last interglacial episode during the late Pleistocene roughly $125,000 \mathrm{y}$ ago. The same species survives in the Gulf of California, today, and occupies a habitat limited to the "low tide mark, on mud flats, and offshore" (Brusca 1980, p. 146).

In summary, the post-Pliocene history of the Volcán Prieto Lagoon tells a story starting with an open embayment occupied by marine invertebrates living in an intertidal to shallow subtidal setting as recently as $125,000 \mathrm{y}$ ago. Under wave attack, coastal erosion of adjacent Volcán Prieto led to the transport of basalt cobbles and boulders to construct a spit that gradually extended in length to close off the Pleistocene embayment. With isolation from open waters in the Gulf of California, the closed lagoon was subject to long periods of aridity interspersed with short spurts of rainfall.

The region's more recent record of episodic rainfall clearly has had an effect on the Volcán Prieto Lagoon. Shallow pools of standing water were observed in the lagoon, when one of the authors (JLV) first visited in 2011. This has possible ramifications for the lagoon's biology, which would need to withstand extreme fluctuations between freshwater immersion and long periods of extreme aridity when the salinity of the
Odile, respectivamente (Johnson y Ledesma-Vázquez 2016). Aunque se degradaron a tormentas tropicales después de tocar tierra en el extremo sur de la península, cerca del trópico de Cáncer (Fig. 1), estos eventos trajeron diluvios repentinos a una zona climática caracterizada como un "dominio seco" normalmente controlado por sistemas de alta presión dominantes alrededor de los $30^{\circ} \mathrm{N}$ (Bailey 1998).

Existe evidencia local de las fuertes lluvias por toda el área aquí estudiada. De manera notable, el piso del cráter del volcán Prieto, con un diámetro de $350 \mathrm{~m}$, está tapizado de limos que en fotografías aéreas se observan como un par de parches blancos (Fig. 2a). La exploración del volcán durante el trabajo de campo confirmó que el material sobre el piso del cráter se derivó de un área de origen restringida en las paredes del cráter circundante. La única explicación para la formación de este depósito es la exposición repetida a lo largo del tiempo a celdas de tormentas que se establecieron sobre el volcán Prieto, incluso por pocas horas a la vez.

El delta Costilla, inmediatamente al norte del volcán Prieto, también atestigua la existencia de eventos de inundación recurrentes que drenaron al arroyo Los Heme a través del tiempo, y que también resultaron en la formación de cauces profundos en el gran terreno volcanoclástico de la región formado en el Plioceno. Debido a la ausencia de piedra pómez en las laderas del volcán Prieto, es probable que los cantos rodados de piedra pómez encontrados en la berma de la laguna al sur se produjeron tierra adentro y fueron acarreados al golfo de California a través del delta Costilla. Una vez en las aguas del golfo, las corrientes litorales transportaron los cantos rodados de piedra pómez a la berma de la laguna. En esencia, estos cantos rodados distintivos varados en la berma de la laguna son el equivalente a los "patitos amarillos" en una tina de baño que flotan y trazan los movimientos del agua. Los cantos rodados y las rocas de basalto que se presentaron de manera más cuantiosa en la berma debieron originarse por la erosión de las costas del volcán Prieto en el lado del golfo.

Los aspectos paleontológicos de la laguna Volcán Prieto indican que anteriormente el sitio era una bahía con conexión abierta al golfo de California. En particular, la "isla" de piedra caliza detrás de la berma en la parte central del frente de la laguna presenta fósiles abundantes dominados por el bivalvo marino C. californiensis. El depósito probablemente data del último episodio interglaciar durante el Pleistoceno tardío hace $\sim 125,000$ años. La misma especie sobrevive en el golfo de California a la fecha, y ocupa un hábitat limitado a la "marca de la marea baja, sobre las planicies lodosas y mar adentro" (Brusca 1980, p. 146).

En resumen, la historia de la laguna Volcán Prieto después del Plioceno empieza con una bahía abierta ocupada por invertebrados marinos que habitaban en zonas intermareales y submareales poco profundas hace tan sólo 125,000 años. Bajo la acción de las olas, la erosión costera del volcán Prieto adyacente ocasionó el transporte de cantos rodados y rocas de basalto para formar una barra que gradualmente se extendió y cerró la bahía pleistocénica. Al aislarse de las aguas abiertas 
lagoon water turns briny. It is likely that the standing water from 2011 was left over from rainfall dropped during the passage of Tropical Depression Georgette, which crossed the region in September 2010.

\section{Significance of local microbial biology}

Previous research by Johnson et al. (2012) on the microbial biology of closed lagoons located farther south of the Puertecitos district in the Bahía de Los Angeles region, in the Gulf of California, identified only a few microbial genera. These were found to include filamentous cyanobacteria such as Phormidium, Oscillatoria, Geitlerinema, and Chroococus together with the solitary cyanobacterium Chroococcidiopis. Older research on lagoons from the Pacific shores of Baja California (Horodyski and Vonder Haar 1975, Horodyski 1977) emphasized even fewer microbial genera dominated by filamentous cyanobacteria such as Microcoleus and Lyngbya together with the solitary cyanobacterium Entophysalis. The current work, which is based on high throughput sequencing of 16S rRNA gene fragments, allowed deeper insights into the microbial diversity than before and revealed a greater number of taxa (OTUs) based on a $97 \%$ similarity exclusion criterion. It also revealed an impressive diversity on higher levels (i.e., order, family, and phyla) for Bacteria and Archaea. Nevertheless, in the surficial sample from $1 \mathrm{~cm}$ depth, lipid biomarkers indicate strong dominance of cyanobacteria, with their lipids representing approximately $40 \mathrm{wt} \%$ of the total lipid inventory. The lipids assigned to cyanobacteria comprise fatty acids with 14 and 16 carbons, but also the highly-specific normal, unsaturated, and methyl-branched heptadecanes and heptadecenes (e.g., Gelpi et al. 1970, Thiel et al. 1997). The latter lipids are exclusively produced by various cyanobacteria.

At least 8 major archaeal phyla and 25 major bacterial phyla were dominant throughout both cores according to amplicon sequencing results (Fig. 4). The majority of archaeal representatives in both cores were largely from newly identified and/or candidate phyla lacking cultured representatives (Hug et al. 2016). In particular, these include the Woesearchaeota and members of the DPANN superphylum (Castelle et al. 2015) (Fig. 5b). Most importantly, the current study supports the potential for a halophilic lifestyle for these archaea. There is a significant possibility that the sediment, at least in the uppermost layers, is highly saline given the presence of a salt crust flooring the lagoon. The salt crust is likely formed through seawater passing throughout the sediment layers of the lagoon and being driven upward by intense evaporation caused by high temperatures in the region. Furthermore, this implies that seawater remaining in the sediment could be highly saturated. Euryarchaeota are common inhabitants of high-saline ecosystems (Andrei et al. 2012), particularly the Halobacteria. Obligate halophiles can withstand salinities 10 times that of seawater ( $\mathrm{Ng}$ et al. 2000). Not unexpectedly, Halobacteria were found throughout all horizons del golfo de California, la laguna cerrada estuvo expuesta a periodos largos de aridez intercalados con eventos cortos de lluvia fuerte.

Las lluvias episódicas más recientes que se han registrado en la región han tenido un efecto claro en la laguna Volcán Prieto. Se observaron pozas poco profundas de agua estancada en la laguna cuando uno de los autores (JLV) visitó el sitio por primera vez en 2011. Esto presenta posibles consecuencias para la biología de la laguna, la cual tendría que soportar fluctuaciones extremas entre periodos de inmersiones en agua dulce y periodos largos de aridez extrema en los cuales la salinidad hace que el agua de la laguna se convierta en salobre. Es probable que el agua estancada en 2011 era el agua remanente de las lluvias ocasionadas por el paso de la tormenta tropical Georgette, que cruzó la región en septiembre de 2010.

\section{Importancia de la biología microbiana local}

Una investigación previa por Johnson et al. (2012) sobre la biología microbiana de lagunas cerradas localizadas más al sur del distrito de Puertecitos en la región de bahía de Los Ángeles, en el golfo de California, identificó sólo unos pocos géneros microbianos. Estos incluyeron cianobacterias filamentosas como Phormidium, Oscillatoria, Geitlerinema y Chroococus, y la cianobacteria solitaria Chroococcidiopsis. Investigaciones anteriores de las lagunas sobre las costas del Pacífico de Baja California (Horodyski y Vonder Haar 1975, Horodyski 1977) destacaron aún menos géneros microbianos dominados por cianobacterias filamentosas como Microcoleus y Lyngbya junto con la cianobacteria solitaria Entophysalis. El presente estudio, el cual se basó en la secuenciación de alto rendimiento de los fragmentos de genes del ARNr 16S, permitió profundizar el conocimiento anterior de la diversidad microbiana y reveló un número mayor de taxones (UTO) basado en un criterio de exclusión de similitud del $97 \%$. También reveló una diversidad impresionante en niveles superiores (i.e., orden, familia y filos) para Bacteria y Archaea. No obstante, en la muestra superficial de la profundidad de $1 \mathrm{~cm}$, los biomarcadores lipídicos indicaron el dominio de cianobacterias; sus lípidos representaron aproximadamente el $40 \% \mathrm{~m} / \mathrm{m}$ del inventario total de lípidos. Los lípidos asignados a cianobacterias incluyen los ácidos grasos con 14 y 16 carbonos, y también los heptadecanos y heptadecenos normales altamente específicos, no saturados y de metil ramificado (e.g., Gelpi et al. 1970, Thiel et al. 1997). Estos últimos lípidos son producidos exclusivamente por varias cianobacterias.

Con base en los resultados de la secuenciación de amplicones, se encontró que al menos 8 filos principales de arqueas y 25 filos principales de bacterias dominaron a lo largo de ambos núcleos (Fig. 4). La mayoría de los representantes arqueales en ambos núcleos pertenecieron a filos recientemente identificados y/o filos candidato que no tienen representantes cultivados (Hug et al. 2016). En particular, estos incluyen Woesearchaeota y miembros del superfilo DPANN (Castelle et al. 2015) (Fig. 5b). Se destaca que el presente 
Kozlowski et al.: Lagoon geomorphology and microbial diversity

of both cores (Fig. 5b). A clear stratification was seen for 2 groups, the Thermoplasmata, mostly confined to the upper $1 \mathrm{~cm}$ of both cores, and the Thaumarchaeota, mostly occurred in the deeper layers (10 and $15 \mathrm{~cm}$, Fig. 5b). The latter group is found commonly and in large amounts in ocean waters and marine sediments and represents chemolithoautotrophic organisms involved in the first step of nitrification. That is, they are known to gain energy from the oxidation of ammonia to nitrite (Schleper and Nicol 2010). Interestingly, this group is not usually associated with hypersaline environments. Thermoplasmatales, particularly marine benthic group D (MBG-D), were found to dominate clone libraries of artificial hypersaline ponds in Guerrero Negro, Baja California Sur, Mexico (Jahnke et al. 2008). The MBG-D were of highest abundance among Thermoplasmatales phylotypes in the present study when looking more in depth at archaeal diversity (data not shown). Regarding archaeal biomarkers, the diether membrane lipids archaeol and extended archaeol were identified in high amounts, representing input from apparently dominant halophilic Euryarchaeota (Dawson et al. 2012). Especially at $5 \mathrm{~cm}$ depth, extended archaeol, a highly specific biomarker for halophilic Euryarchaeota, was very abundant. The other archaea identified by high throughput sequencing of 16S rRNA gene fragments could not be recognized by lipid biomarkers, probably due to too low contents or the lack of specific lipids. However, since the lipid biomarker inventories of the newly identified and/or candidate phyla lacking cultured representatives are not known to date, future work may allow for the detection of these phyla with biomarkers.

Bacteria made up the significant portion of OTUs, from $70 \%$ to $95 \%$, in both cores at all horizons (Table 1). Although Planctomycetes and Chloroflexi were dominant bacterial phyla in both cores (Fig. 4), a great diversity of bacterial phyla was recognized in all core horizons (Fig. 5a) in agreement with previous findings on the hypersaline microbial mats of Guerro Negro (Ley et al. 2006). Stratification among the different horizons at the Volcán Prieto Lagoon was less pronounced for archaea in comparison to bacteria; however, more replicate cores would be needed to confirm such statement. Comparable studies of bacterial diversity in certain saline ecosystems that also used high throughput sequencing have found similar phyla as the current study (Canfora et al. 2014), but also suggest a need for further research on the topic as many of the phyla not normally associated with high salinity are among the dominant community members. We assume that the large diversity in this extreme arid setting is favored by the fluctuations in salinity, which in turn favors the propagation of microorganisms with different adaptations (from medium to high salinity) either at different times or in different layers of the growing biofilm. It is also likely that a fluctuation in nutrient input throughout the lagoon sediment, particularly as seawater is driven upward, would cause stratification of microorganisms based on metabolic adaptation to available electron donors and acceptors. Important analyses on sediments of the lagoon that go beyond estudio reitera el potencial de estas arqueas para mantener una vida halófila. Hay una posibilidad significativa de que el sedimento, por lo menos de las capas superficiales, sea altamente salino debido a la presencia de una costra salina que cubre la laguna. Es probable que la costra salina se formó por el paso del agua de mar a través de las capas de sedimento de la laguna que es llevada hacia la superficie por la evaporación intensa causada por las altas temperaturas en la región. Además, esto implica que el agua de mar que permanece en el sedimento podría estar sumamente saturada. Las euriarqueotas son habitantes comunes de ecosistemas altamente salinos (Andrei et al. 2012), particularmente las halobacterias. Los halófilos obligados pueden soportar salinidades 10 veces más altas que la del agua de mar ( $\mathrm{Ng}$ et al. 2000). Como era de esperarse, se encontraron halobacterias en todos los horizontes de ambos núcleos (Fig. 5b). Se observó una estratificación clara para 2 grupos, Thermoplasmata, confinados principalmente a la capa superior correspondiente a $1 \mathrm{~cm}$ de profundidad en ambos núcleos, y Thaumarchaeota, principalmente presente en capas más profundas $(10 \mathrm{y} 15 \mathrm{~cm}$, Fig. 5b). El segundo grupo se encuentra de manera común $\mathrm{y}$ en grandes cantidades en aguas y sedimentos marinos $\mathrm{y}$ representa a los organismos quimiolitoautótrofos involucrados en el primer paso de nitrificación. Es decir, se sabe que obtienen energía por medio de la oxidación de amoniaco a nitrato (Schleper y Nicol 2010). Es interesante destacar que este grupo normalmente no se asocia con ambientes hipersalinos. Se encontró que los Thermoplasmatales, en particular los bentónicos marinos del grupo D (BMG-D), dominaron las bibliotecas de clones de estanques hipersalinos artificiales en Guerrero Negro, Baja California Sur, México (Jahnke et al. 2008). Los BMG-D presentaron la mayor abundancia entre los filotipos de Thermoplasmatales en el presente estudio cuando se estudió la diversidad de Archaea de manera más detallada (datos no mostrados). En cuanto a los biomarcadores arqueales, los lípidos diéteres de membranas arqueol $\mathrm{y}$ arqueol extendido fueron identificados en grandes cantidades, lo que representa el aporte del filo halofílico aparentemente dominante Euryarchaeota (Dawson et al. 2012). Especialmente a $5 \mathrm{~cm}$ de profundidad, el arqueol extendido, un biomarcador altamente específico para el filo halofílico Euryarchaeota, fue muy abundante. La otra arquea identificada por secuenciación de alto rendimiento de los fragmentos de genes del ARNr 16S no pudo ser reconocida por medio de biomarcadores lípidos, probablemente debido a contenidos demasiado bajos o la ausencia de lípidos específicos. Sin embargo, debido a que los inventarios de los biomarcadores lipídicos de filos identificados recientemente o filos candidatos que no tienen representantes cultivados no se conocen actualmente, los futuros estudios podrían permitir la detección de estos filos con biomarcadores.

Un porción significativa, de $70 \%$ a $95 \%$, de las UTO estuvo formada por Bacteria en ambos núcleos en todos los horizontes (Tabla 1). Aunque Planctomycetes y Chloroflexi fueron filos bacterianos dominantes en ambos núcleos 
taxonomic affiliation are still needed to elucidate the active microbial communities. These should include metagenomic and metatranscriptomic approaches. These approaches could (1) provide new genomes of phyla for which there are currently no, or very few, sequenced representatives; (2) highlight functional redundancies within the communities as well as unique niches; (3) showcase metabolic diversity of bacteria and archaea found in saline environments; and (4) provide a further marker for active and non-active members within the community.

The lipid biomarker inventories revealed significant changes with depth (Fig. 6). At $1 \mathrm{~cm}$ depth cyanobacteria predominated, indicated by the high abundance of heptadecanes (Gelpi et al. 1970, Thiel et al. 1997), and the only other group that contributed significantly to biomass production were anoxygenic phototrophic bacteria, indicated by the presence of a $\mathrm{cycC}_{19: 0}$ fatty acid (e.g., Grimalt et al. 1992, Bühring et al. 2009). At $5 \mathrm{~cm}$ depth cyanobacteriaspecific lipids disappeared, but chlorophyll and algal markers remained present with around $16 \mathrm{wt} \%$. Anoxygenic phototrophic bacteria decreased $(8 \mathrm{wt} \%)$ at this depth, but other unknown bacteria increased to $14 \mathrm{wt} \%$; some of the lipids that cannot be assigned to specific bacterial lineages include hopanoids. However, the terminally branched fatty acids could be assigned to sulfate-reducing bacteria (e.g., Heindel et al. 2012), representing $5 \mathrm{wt} \%$ of all lipids at $5 \mathrm{~cm}$ depth. Whereas anoxygenic phototrophic bacteria became less abundant with depth, sulfate-reducing bacteria slightly increased with depth.

The area south of Puertecitos in the San Felipe Desert Subregion along the Upper Gulf of California is special for its rich physical landmarks and the high level of microbial biodiversity discovered in natural salt lagoons. The closed lagoon studied here retains sufficient physical evidence to reconstruct its origins from an open embayment with normal marine circulation on the sheltered side of a Pliocene volcano. Over time, extension of a spit composed of coarse clastic materials eroded from the extinct volcano's shoreline closed off the embayment to create an isolated lagoon. Recent history of the Volcán Prieto Lagoon suggests that prolonged periods of extreme aridity are punctuated by brief episodes of intense rainfall lasting perhaps only hours. Such a lagoon setting with wide variations in standing floodwater reverting to salt brine provides a refuge habitat distinctly suitable for microbial life.

Our study indicates that a great diversity of microorganisms of well-known and also recently discovered, but currently uncharacterized, bacterial and archaeal phyla thrive in natural lagoons. It is of great interest for future studies to distinguish actively growing cells from dormant or dead material that accumulates as the biofilms accumulate in this fluctuating environment. In addition, further studies are needed to confirm the present finding with respect to temporal changes in community composition, as well as analyzing other similar settings in different regions of the Gulf. This will allow
(Fig. 4), se identificó una gran diversidad de filos bacterianos en todos los horizontes (Fig. 5a) que concuerda con lo encontrado en mantos microbianos hipersalinos en Guerrero Negro (Ley et al. 2006). La estratificación entre los diferentes horizontes de la laguna Volcán Prieto fue menos pronunciada para las arqueas que para las bacterias; sin embargo, se necesitarían más réplicas de núcleos para confirmar esta declaración. Los estudios comparables sobre la diversidad bacteriana en ciertos ecosistemas salinos que también utilizaron secuenciación de alto rendimiento encontraron filos similares a los encontrados en el presente estudio (Canfora et al. 2014), pero también sugieren que existe una necesidad de investigar más este tema ya que muchos de los filos que normalmente no se relacionan con altas salinidades estuvieron entre los miembros dominantes de la comunidad. Suponemos que la gran diversidad en este ambiente extremadamente árido es propiciada por las fluctuaciones en la salinidad, que a su vez favorecen la propagación de microorganismos con diferentes adaptaciones (de salinidades medias a altas) ya sea en diferentes tiempos o en diferentes capas del crecimiento de la biopelícula. También es probable que una fluctuación en el aporte de nutrientes a través del sedimento de la laguna, particularmente conforme el agua de mar se eleva a la superficie, causaría una estratificación de los microorganismos por sus adaptaciones metabólicas a la disponibilidad de donadores y aceptores de electrones. Aún se necesitan más análisis de los sedimentos de la laguna que vayan más allá de la afiliación taxonómica para dilucidar las comunidades microbianas activas. Estos deben incluir estudios metagenómicos y metatranscriptómicos. Estos estudios podrían (1) proporcionar nuevos genomas de filos para los cuales actualmente no existen, o hay muy pocos, representantes secuenciados; (2) resaltar redundancias funcionales dentro de comunidades, así como nichos únicos; (3) demostrar la diversidad metabólica de las bacterias y arqueas encontradas en ambientes salinos; y (4) proporcionar marcadores adicionales para miembros activos y no activos dentro de la comunidad.

Los inventarios de los biomarcadores lipídicos revelaron cambios significativos con la profundidad (Fig. 6). A $1 \mathrm{~cm}$ de profundidad, las cianobacterias predominaron, lo cual se identificó por la alta abundancia de heptadecanos (Gelpi et al. 1970, Thiel et al. 1997), y el único otro grupo que contribuyó de manera significativa a la producción de biomasa fue el de las bacterias fototróficas anoxigénicas, identificado por la presencia del ácido graso ciclopropano $\left(\mathrm{C}_{19: 0} \mathrm{cic}\right)$ (e.g., Grimalt et al. 1992, Bühring et al. 2009). A $5 \mathrm{~cm} \mathrm{de}$ profundidad, los lípidos específicos de cianobacterias desaparecieron, pero los marcadores de clorofila y algas permanecieron presentes con cerca del $16 \% \mathrm{~m} / \mathrm{m}$. Las bacterias fototróficas anoxigénicas disminuyeron $(8 \% \mathrm{~m} / \mathrm{m})$ a esta profundidad, pero otras bacterias desconocidas incrementaron a $14 \% \mathrm{~m} / \mathrm{m}$; algunos de los lípidos que no se pudieron asignar a linajes bacterianos específicos incluyen los hopanoides. Sin embargo, los ácidos grasos con ramificaciones terminales podrían ser asignados a bacterias reductoras de 
Kozlowski et al.: Lagoon geomorphology and microbial diversity

for statistical analyses of microbial community compositions in the context of different geographical and environmental parameters through a north-south climatic moisture gradient to understand which factors drive diversity.

\section{ACKNOWLEDGMENTS}

Original fieldwork in the Puertecitos area (Baja California, Mexico) was conducted on 14 May 2016 by MEJ and JLV with financial support through a research grant from the Science Division at Williams College covering travel and field expenses. JAK was financed through the European Research Council Advanced Grant ERC-ADG 695192 to CS. We thank Romana Bittner (University of Vienna) for excellent technical support with the high throughput amplicon sequencing. Comments by 2 anonymous referees helped to improve the manuscript.

\section{REFERENCES}

Andrei A-S, Banciu HL, Oren A. 2012. Living with salt: metabolic and phylogenetic diversity of archaea inhabiting saline ecosystems. FEMS Microbiol. Lett. 330(1): 1-9. https://doi.org/10.1111/j.1574-6968.2012.02526.x

Backus DH, Johnson ME. 2014. Stromatolitic mats from an uplifted Pleistocene lagoon at Punta Chivato on the Gulf of California (Mexico). Palaios 29(9): 460-466. https://doi.org/10.2110/palo.2013.114

Bailey RG. 1998. Ecoregions-The Ecosystem Geography of the Oceans and Continents. Springer, New York, $176 \mathrm{pp}$.

Birgel D, Elvert M, Han X, Peckmann J. 2008. ${ }^{13}$ C-depleted biphytanic diacids as tracers of past anaerobic oxidation of methane. Org. Geochem. 39(1): 152-156. https://doi.org/10.1016/j.orggeochem.2007.08.013

Brusca RC. 1980. Common Intertidal Invertebrates of the Gulf of California. 2nd ed. University of Arizona Press, Tucson (AZ), 513 pp.

Bühring SI, Smittenberg RH, Sachse D, Lipp JS, Golubic S, Sachs JP, Hinrichs K-U, Summons RE. 2009. A hypersaline microbial mat from the Pacific Atoll Kiritimati: insights into composition and carbon fixation using biomarker analyses and a ${ }^{13} \mathrm{C}$-labeling approach. Geobiology 7(3): 308-323. https://doi.org/10.1111/j.1472-4669.2009.00198.x

Canfora L, Bacci G, Pinzari F, Lo Papa G, Dazzi C, Benedetti A. 2014. Salinity and bacterial diversity: To what extent does the concentration of salt affect the bacterial community in a saline soil? PLoS ONE 9(9): e106662. https://doi.org/10.1371/journal.pone.0114658

Caporaso JG, Kuczynski J, Stombaugh J, Bittinger K, Bushman FD, Costello EK, Fierer N, Peña AG, Goodrich JK, Gordon JI, et al. 2010. QIIME allows analysis of high-throughput community sequencing data. Nat. Methods 7(5): 335-336. https://doi.org/10.1038/nmeth.f.303

Castelle CJ, Wrighton KC, Thomas BC, Hug LA, Brown CT, Wilkins MJ, Frischkorn KR, Tringe SG, Singh A, Markillie LM, et al. 2015. Genomic expansion of domain Archaea highlights roles of organisms from new phyla in anaerobic carbon cycling. Curr. Biol. 25(6): 690-701. https://doi.org/10.1016/j.cub.2015.01.014

Dawson KS, Freeman KH, Macalady JL. 2012. Molecular characterization of core lipids from halophilic archaea grown under different salinity conditions. Org. Geochem. 48: 1-8. https://doi.org/10.1016/j.orggeochem.2012.04.003 sulfato (e.g., Heindel et al. 2012), que representaron $5 \% \mathrm{~m} / \mathrm{m}$ de todos los lípidos a $5 \mathrm{~cm}$ de profundidad. Mientras que las bacterias fototróficas anoxigénicas fueron menos abundantes con la profundidad, las bacterias reductoras de sulfato incrementaron un poco con la profundidad.

El área al sur de Puertecitos en la subregión del desierto de San Felipe a lo largo del Alto Golfo de California es especial por la riqueza de sus elementos geográficos y el alto nivel de biodiversidad microbiana descubierto en las lagunas saladas naturales. La laguna cerrada aquí estudiada conserva suficiente evidencia física para reconstruir su origen desde una bahía abierta con circulación marina normal en el lado protegido de un volcán pliocénico. A lo largo del tiempo, la extensión de una barra compuesta de material clástico grueso, erosionado de la línea de costa del volcán extinto, cerró la bahía y creó una laguna aislada. La historia reciente de la laguna Volcán Prieto sugiere que lo periodos prolongados de aridez fueron interrumpidos por periodos breves de lluvia intensa que posiblemente duraron solamente horas. Este ambiente lagunar con grandes variaciones de agua estancada revirtiéndose a salmuera proporciona un hábitat de refugio distintivamente apto para la vida microbiana.

Nuestro estudio indica que una gran diversidad de microorganismos de filos bacterianos y arqueales bien conocidos y también recién descubiertos, pero no caracterizados actualmente, prosperan en lagunas naturales. Para trabajos futuros, es de gran interés distinguir a las células con crecimiento activo del material latente o muerto que se acumula conforme se acumulan las biopelículas en este ambiente fluctuante. Adicionalmente, se requieren más estudios para confirmar el hallazgo actual con respecto a los cambios temporales en la composición comunitaria, así como para analizar otros ambientes similares en diferentes regiones del golfo. Esto permitirá el análisis estadístico de la composición de la comunidad microbiana en el contexto de diferentes parámetros geográficos y ambientales a través de un gradiente climático de humedad norte-sur para entender cuáles factores propician la diversidad.

Traducido al español por Claudia Michel-Villalobos

\section{Agradecimientos}

El trabajo de campo original en el área de Puertecitos (Baja California, México) se realizó el 14 de mayo de 2016 por MEJ y JLV con el apoyo financiero de la División de Ciencias de Williams College a través de una beca de investigación para sufragar los gastos de viaje y de campo. JAK recibió apoyo financiero a través de las subvenciones avanzadas del Consejo Europeo de Investigación por medio de la beca ERC-ADG 695192 otorgada a CS. Agradecemos el excelente apoyo técnico brindado por Romana Brittner (Universidad de Viena) para la secuenciación de amplicones de alto rendimiento. Los comentarios de 2 revisores anónimos ayudaron a mejorar el trabajo. 
Gastil RG, Phillips RP, Allison EC. 1971. Reconnaissance Geologic Map of the State of Baja California [map sheet b]. Geological Society America Memoir, 140, Boulder (CO).

Gelpi E, Schneider H, Mann J, Oró J. 1970. Hydrocarbons of geochemical significance in microscopic algae. Phytochemistry 9(3): 603-612. https://doi.org/10.1016/s0031-9422(00)85700-3

Gittel A, Bárta J, Kohoutová I, Mikutta R, Owens S, Gilbert J, Schnecker J, Wild B, Hannisdal B, Maerz J, et al. 2014. Distinct microbial communities associated with buried soils in the Siberian tundra. ISME J. 8(4): 841-853. https://doi.org/10.1038/ismej.2013.219

Grimalt JO, De Wit R, Teixidor P, Albaigés J. 1992. Lipid biogeochemistry of Phormidium and Microcoleus mats. Org. Geochem. 19(4-6): 509-530. https://doi.org/10.1016/0146-6380(92)90015-p

Heindel K, Birgel D, Brunner B, Thiel V, Westphal H, Gischler E, Ziegenbalg SB, Cabioch G, Sjövall P, Peckmann J. 2012. Postglacial microbialite formation in coral reefs of the Pacific, Atlantic, and Indian Oceans. Chem. Geol. 304-305: 117-130. https://doi.org/10.1016/j.chemgeo.2012.02.009

Horodyski RJ. 1977. Environmental influences on columnar stromatolite branching patters: examples from the Middle Proterozoic Belt Subgroup, Glacier National Park, Montana. J. Paleontol. 51:661-671

Horodyski RJ, Vonder Haar SP. 1975. Recent calcareous stromatolites from Laguna Mormona (Baja California) Mexico. J. Sediment. Petrol. 45(4): 894-906. https://doi.org/10.1306/212F6E7E-2B24-11D7-8648000102C1865D

Hug LA, Baker BJ, Anantharaman K, Brown CT, Probst AJ, Castelle CJ, Butterfield CN, Hernsdorf AW, Amano Y, Ise K, et al. 2016. A new view of the tree of life. Nat. Microbiol. 1: 16048. https://doi.org/10.1038/nmicrobiol.2016.48

Jahnke LL, Orphan VJ, Embaye T, Turk KA, Kubo MD, Summons RE, Des Marais DJ. 2008. Lipid biomarker and phylogenetic analyses to reveal archaeal biodiversity and distribution in hypersaline microbial mat and underlying sediment. Geobiology 6(4): 394-410. https://doi.org/10.1111/j.1472-4669.2008.00165.x

Johnson ME, Ledesma-Vázquez J. 2016. Gulf of California Coastal Ecology: Insights from the Present and Patterns from the Past. Sunbelt Publications, San Diego (CA), 134 pp.

Johnson ME, Ledesma-Vázquez J, Backus DH, González MR. 2012. Lagoon microbialites on Isla Angel de la Guarda and associated peninsular shores, Gulf of California (Mexico). Sediment. Geol. 263-264: 76-84. https://doi.org/10.1016/j.sedgeo.2011.09.006

Ley RE, Harris JK, Wilcox J, Spear JR, Miller SR, Bebout BM, Maresca JA, Bryant DA, Sogin ML, Pace NR. 2006.
Unexpected diversity and complexity of the Guerrero Negro Hypersaline Microbial Mat. Appl. Environ. Microbiol. 72(5): 3685-3695. https://doi.org/10.1128/aem.72.5.3685-3695.2006

Ng WV, Kennedy SP, Mahairas GG, Berquist B, Pan M, Shukla HD, Lasky SR, Baliga NS, Thorsson V, Sbrogna J, et al. 2000. Genome sequence of Halobacterium species NRC-1. Proc. Natl. Acad. Sci. USA 97(22): 12176-12181. https://doi.org/10.1073/pnas.190337797

Omoregie EO, Crumbliss LL, Bebout BM, Zehr JP. 2004 Determination of nitrogen-fixing phylotypes in Lyngbya sp. and Microcoleus chthonoplastes cyanobacterial mats from Guerrero Negro, Baja California, Mexico. Appl. Environ. Microbiol. 70(4): 2119-2128. https://doi.org/10.1128/aem.70.4.2119-2128.2004

Quast C, Pruesse E, Yilmaz P, Gerken J, Schweer T, Yarza P, Peplies J, Glöckner FO. 2013. The SILVA ribosomal RNA gene database project: improved data processing and web-based tools. Nucleic Acids Res. 41(D1): D590-D596. https://doi.org/10.1093/nar/gks1219

Rebman JP, Roberts NC. 2012. Baja California Plant Field Guide. 3rd ed. San Diego Natural History Museum and Sunbelt Publications, San Diego (CA), 451 pp.

Romero-Vadillo E, Zaytsev O, Morales-Pérez R. 2007. Tropical cyclone statistics in the northeastern Pacific. Atmósfera 20(2): 197-213.

Schleper C, Nicol GW. 2010. Ammonia-oxidising archaea-physiology, ecology and evolution. Adv. Microb. Physiol. 57: 1-41. https://doi.org/10.1016/b978-0-12-381045-8.00001-1

Spear JR, Ley RE, Berger AB, Pace NR. 2003. Complexity in natural microbial ecosystems: The Guerrero Negro experience. Biol. Bull. 204(2): 168-173. https://doi.org/10.2307/1543553

Stock JM. 2000. Relation of the Puertecitos volcanic province, Baja California, Mexico, to development of the plate boundary in the Gulf of California. In: Delgado-Granados H, Aguirre-Díaz G, Stock JM (eds.), Cenozoic Tectonics and Volcanism of Mexico. Geological Society of America Special Paper 334, Boulder (CO), pp. 143-156. https://doi.org/10.1130/0-8137-2334-5.143

Stolz JF. 1983. Fine structure of the stratified microbial community at Laguna Figueroa, Baja California, Mexico. I. Methods of in situ study of the laminated sediments. Precambrian Res. 20(2-4): 479-492. https://doi.org/10.1016/0301-9268(83)90086-4

Thiel V, Merz-Preiß M, Reitner J, Michaelis W. 1997. Biomarker studies on microbial carbonates: Extractable lipids of a calcifying cyanobacterial mat (Everglades, USA). Facies 36(1): $163-172$.
Received August 2017, accepted January 2018. 